

\title{
ENVIRONMENTAL RADIATION MEASUREMENTS AT THE FORMER SOVIET UNION'S SEMIPALATINSK NUCLEAR TEST SITE AND SURROUNDING VILLAGES
}

\author{
Peter Shebell and Adam R. Hutter \\ Environmental Measurements Laboratory \\ U. S. Department of Energy \\ 201 Varick Street, NY 10014-4811
}

July 1996

\section{DISCLAIMER}

"This report was prepared as an account of work sponsored by an agency of the United States Government. Neither the United States Government nor any agency thereof, nor any of their employees, makes any warranty, express or implied, or assumes any legal liability or responsibility for the accuracy, completeness, or usefulness of any information, apparatus, product, or process disclosed, or represents that its use would not infringe privately owned rights. Reference herein to any specific commerclal product, process, or service by trade name, trademark, manufacturer, or otherwise, does not necessarily constitute or imply its endorsement, recommendation, or favoring by the United States Government or any agency thereof. The views and opinions of authors expressed herein do not necessarily state or reflect those of the United States Government or any agency thereof."

This report has been reproduced directly from the best available copy.

Available from the National Technical Information Service, U.S. Department of Commerce, 5285 Port Royal Road, Springfield, Virginia 22161. 


\section{DISCLAIMER}

Portions of this document may be illegible in electronic image products. Images are produced from the best available original document. 
Two scientists from the U.S. Department of Energy's Environmental Measurements Laboratory served as scientific experts to the International Atomic Energy Agency's (IAEA) Mission to Kazakhstan: Strengthening Radiation and Nuclear Safety Infrastructures in Countries of the former USSR, Special Task - Preassessment of the radiological situation in the Semipalatinsk and western areas of Kazakhstan. The former Soviet Union's largest nuclear test site was located near Semipalatinsk, Kazakhstan, and following Kazakhstan's independence, the IAEA committed to studying the environmental contamination and the resulting radiation exposure risk to the population due to 346 underground, 87 atmospheric and 26 surface nuclear detonations performed at the site between 1949 and 1989. As part of an 11-member team, environmental radiation measurements were performed during 2 weeks in July 1994. Approximately 30 sites were visited both within the boundaries of the Semipalatinsk nuclear test site as well as in and around surrounding villages. Specifically, the objectives of the EML team were to apply independent methods and equipment to assess potential current radiation exposures to the population. Towards this end, the EML scientists collected in-situ gamma-ray spectra, performed external gamma dose rate measurements using pressurized ionization chambers, and collected soil samples in order to estimate the inventory and to determine the depth distribution of radionuclides of interest. With the exception of an area near an "atomic lake" and a $1 \mathrm{~km}^{2}$ area encompassing ground zero, all the areas visited by the team had external dose rates that were within typical environmental levels. The measurements taken within a $15 \mathrm{~km}$ radius of ground zero had elevated levels of ${ }^{137} \mathrm{Cs}$ as well as the activation products ${ }^{152} \mathrm{Eu}$ and ${ }^{60} \mathrm{Co}$. The dose rate within a $1 \mathrm{~km}$ radius of ground zero ranged from 500 to $30000 \mathrm{nGy} \mathrm{h}^{-1}$. 


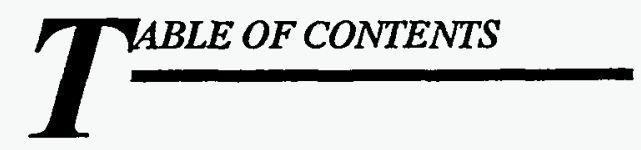

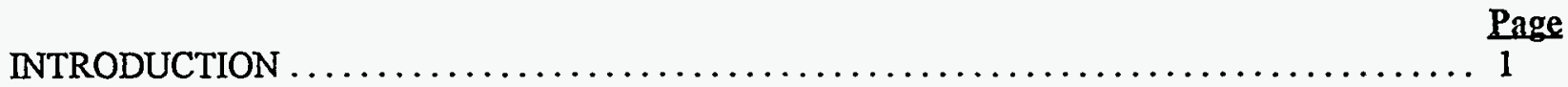

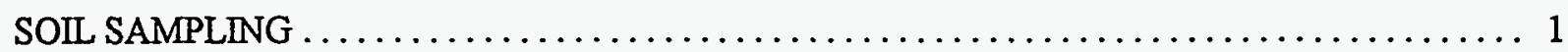

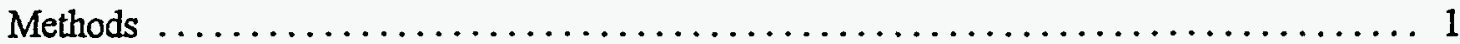

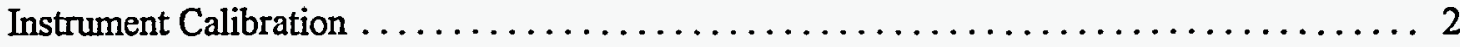

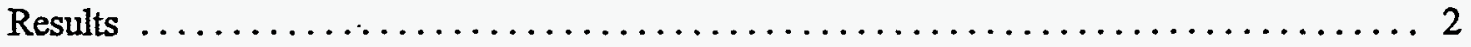

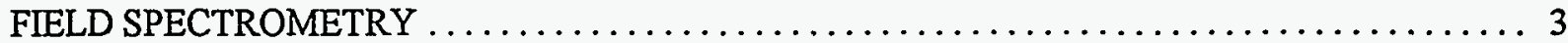

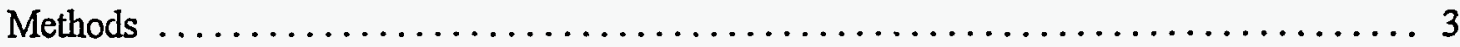

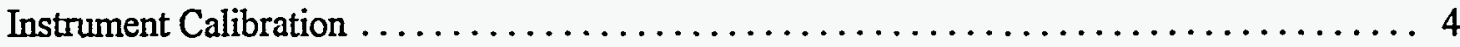

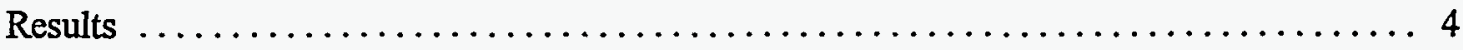

EXTERNAL GAMMA DOSE RATE MEASUREMENTS $\ldots \ldots \ldots \ldots \ldots \ldots \ldots \ldots \ldots \ldots \ldots$

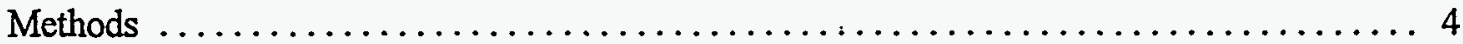

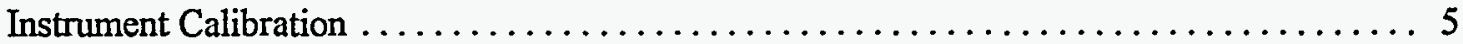

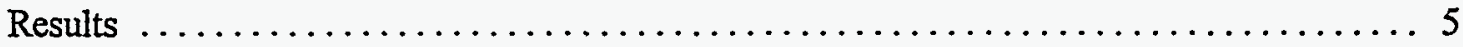

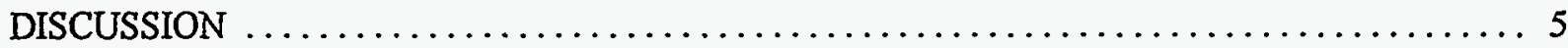

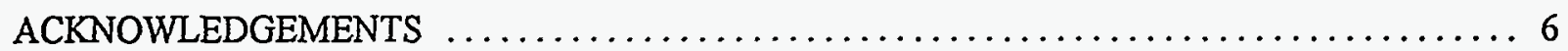

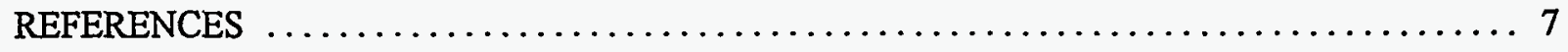

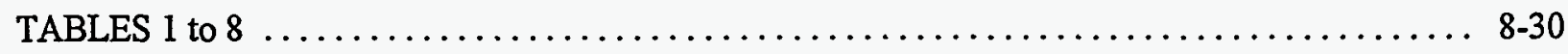

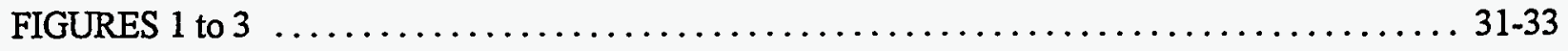

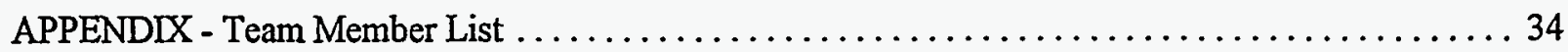




\section{NTRODUCTION}

Two scientists from the U. S. Department of Energy's Environmental Measurements Laboratory served as scientific experts to the International Atomic Energy Agency's (IAEA) Mission to Kazakhstan, "Strengthening Radiation and Nuclear Safety Infrastructures in Countries of the former USSR, Special Task - Preassessment of the radiological situation in the Semipalatinsk and western areas of Kazakhstan". The former Soviet Union's largest nuclear test site was located near Semipalatinsk, Kazakhstan, and following Kazakhstan's independence, the IAEA committed to studying the environmental contamination and the resulting radiation exposure risk to the population due to 346 underground, 87 atmospheric and 26 surface nuclear detonations performed at the site between 1949 and 1989. As part of an 11-member team (see the Appendix for team member list), with participants from the United Kingdom, France, Austria and Russia, environmental radiation measurements were performed during 2 weeks in July 1994. Approximately 30 sites were visited both within the boundaries of the Semipalatinsk nuclear test site, as well as in and around surrounding villages. Specifically, the objectives of the EML team were to apply independent methods and equipment to assess potential current radiation exposures to the population. The test site is an uncontrolled area, and since nomadic peoples and herds are prevalent, the preassessment effort needed to address any location where the population could be exposed, as well as different exposure pathways. Therefore, significant time and effort was spent in the villages closest to the test site as well as within the borders of the test site. Towards this end, the EML scientists collected in situ gamma-ray spectra, performed external gamma dose rate measurements using pressurized ionization chambers (PICs), and collected soil samples in order to estimate the inventory and to determine the depth distribution of radionuclides of interest.

While at the test site, EML was guided by personnel who had been involved with the testing of nuclear devices at the site. This report details the EML measurements and samples collected from locations where it was escorted, including excavation lakes and the ground zero for surficial tests. There were other possible contaminated areas where the team did not survey, including "technical areas" and near the reactors.

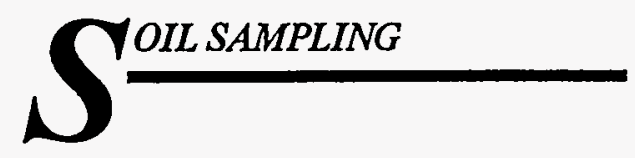

\section{METHODS}

Soil samples were collected to estimate the inventory and to determine the depth distribution of ${ }^{137} \mathrm{Cs}$, ${ }^{152} \mathrm{Eu},{ }^{155} \mathrm{Eu},{ }^{60} \mathrm{Co},{ }^{241} \mathrm{Am}$ and ${ }^{154} \mathrm{Eu}$. Soil samples were collected at locations where gamma-ray exposure data indicated reasonable local uniformity (see Table 1 for description and identification of sample locations, and Figure 1 for a map of sample locations). Almost all soil samples were collected in flat, undisturbed areas used for grazing cattle, sheep and/or horses, thus having short-cropped vegetation. Samples were collected using $8.9-\mathrm{cm}$ diameter soil cutters. A 5-cm deep cut was removed, followed by a 10-cm corer inserted into the same hole to obtain a 5 to $10-\mathrm{cm}$ cut, and finally, a $15-\mathrm{cm}$ corer was used to obtain a 10 to $15-\mathrm{cm}$ cut. In some instances, a core down to $30 \mathrm{~cm}$ was obtained using an auger. This sampling procedure is described in the EML Procedures Manual, Section 2.4.3.1 (Chieco et al., 1992). 
Due to time, weight and other logistical considerations, all sites were sampled using three cores. The samples were collected at approximately equidistant locations and $3 \mathrm{~m}$ from the gamma spectrometer. The surface area collected using this technique $\left(186 \mathrm{~cm}^{2}\right)$ does not represent the site as precisely as the normal 10-core sample as per ASTM procedures (ASTM 1983). However, our experience in soil analyses indicates that the total error in the sampling, preparation and the gamma analysis will be about $15 \%$ for the three-core samples as opposed to an estimated $8 \%$ error when using the 10 -core method. The respective cuts of the soil from the three cores were composited, broken up by hand, and homogenized as well as possible. The sample was then spread out on a plastic tarp and quartered, with stones and vegetation evenly distributed. Two of the quarters were kept, resulting in an approximate split of the sample so as to reduce the sample size.

In the laboratory, the soil samples were air dried for 3-10 days in plastic trays. The samples were not sieved but large stones were removed before the samples were sealed in $90-\mathrm{mL}$ aluminum cans. The samples were then allowed to stand for several weeks so that the radon progeny could build into equilibrium. A HPGe spectrometer system comprised of a reversed bias $35 \%$ efficiency (relative to a $7.62 \times 7.62 \mathrm{~cm} \mathrm{NaI}$ crystal at $1332 \mathrm{keV}$ ) was used to analyze the samples. The energy region examined was 20 to $3000 \mathrm{keV}$, and counting times ranged from one to several days depending on the activity of the sample and desired accuracy of the results.

One set of duplicate samples was obtained which translates into a frequency of about $10 \%$ ( 1 in 9 samples).

\section{INSTRUMENT CALIBRATION}

The HPGe detector used for the analysis of the samples was calibrated using 70-mL NIST traceable standards containing the radionuclides ${ }^{137} \mathrm{Cs},{ }^{60} \mathrm{Co}$ and ${ }^{241} \mathrm{Am}$ housed in aluminium cans. The calibration procedures are detailed in the EML Procedures Manual, Section 4.5.2.3 (Chieco et al., 1992). Deionized water samples were counted on a weekly basis to check for possible contamination and fluctuations in background. A periodic check of the efficiency with a ${ }^{137} \mathrm{Cs}$ reference material also sealed in $90-\mathrm{mL}$ aluminum can was performed. The total systematic error for all concentrations, with the exception of

${ }^{152} \mathrm{Eu}$, are $<5 \%$. Effects of cascade coincident summing raised the total systematic error for ${ }^{152} \mathrm{Eu}$ to about $10 \%$.

\section{RESULTS}

A summary of absorbed dose rate in air calculated from the soil samples is shown in Table 2. For comparison and quality assurance (QA) purposes, this table includes estimates of the dose rates using field spectrometric methods (see following sections), as well as estimates using the results of soil sampling. Soil data and concentration values for natural and anthropogenic radionuclides are summarized in Table 3. The principal gamma emitters detected again varied with location. At all locations ${ }^{137} \mathrm{Cs}$ was detected along with other peaks connected with naturally occurring radionuclides. The ground zero samples (Location IDs 725.1 - 726.GZ), consisting of cores taken at distances ranging from 1 to $\sim 10 \mathrm{~km}$ from ground zero were found to contain ${ }^{152} \mathrm{Eu},{ }^{155} \mathrm{Eu},{ }^{60} \mathrm{Co}$ and ${ }^{241} \mathrm{Am}$. A sample taken about $200 \mathrm{~m}$ from historical ground zero (Location ID 726.GZ) was found to contain ${ }^{154} \mathrm{Eu}$ as well. A sample of loose gravel was taken from the edge of an excavation lake $\sim 15 \mathrm{~km}$ outside of Sarzhal (Location ID 720.3) with the suspicion that a sufficient amount of plutonium might be present to assay by gamma analysis. 
The concentration of ${ }^{239} \mathrm{Pu}$ was determined by analyzing the $393 \mathrm{keV}$ doublet. Although weak, with an emission rate of 5.53E-6 $\gamma /$ disintegration, this line was chosen because corrections for coincident summing are not necessary (Debertin \& Helmer, 1988). Concentrations of ${ }^{241} \mathrm{Am}$ and ${ }^{239} \mathrm{Pu}$ are reported in Table 3, but we must emphasize that this was not the result of our standard soil sampling techniques.

The gamma analysis of the samples from ground zero, Lake Tchagan, and the excavation lake (location IDs 726.GZ, 719.1, and 720.3, respectively) were problematic. Peak interference and cascade coincident summing effects puts the total systematic error on these sample at about $15 \%$. Just as with the in situ spectra, the resulting concentrations for each of the natural emitters, and inventories for the various gamma emitters, ${ }^{137} \mathrm{Cs},{ }^{152} \mathrm{Eu}$, etc., can be converted to dose rate in air. Each contribution can then be added to an appropriate value for the cosmic-ray contribution. The resulting dose rate can than be compared to PIC measurements (see subsequent sections). Agreement to within $15 \%$ is an indication of good sample preparation and detector calibration.

Inventory estimates for these nuclides in $\mathrm{kBq} \mathrm{m}^{-2}$ can be found in Table 4. Included in this table is the relaxation mass per unit area that was used to determine absorbed dose rates in air from the given inventories.

Dose rate estimates for these nuclides as well as ${ }^{226} \mathrm{Ra}$, ${ }^{228} \mathrm{Ra}$, and ${ }^{40} \mathrm{~K}$ can be found in Table 5. A cosmic component of $34.2 \mathrm{nGy} \mathrm{h}^{-1}$ was included to produce a dose rate which could be compared to measurements taken with a PIC.

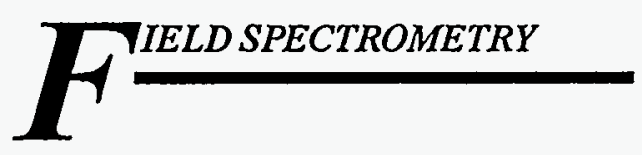

\section{METHODS}

A tripod mounted HPGe detector (45\% efficiency relative to a $7.62 \times 7.62 \mathrm{~cm} \mathrm{NaI}$ crystal at 1332 $\mathrm{keV}$ ) was used in conjunction with a battery powered EG\&G Ortec "Nomad" multichannel analyzer (MCA) to collect the gamma-ray spectra at the selected sites. The standard reference height of $1 \mathrm{~m}$ above the ground was used in all cases. The energy region examined was $50-4000 \mathrm{keV}$, with a collection time of $10 \mathrm{~min}$. Selection of the specific measurement location was based on the terrain. The best sites are those that approximate a $2 \pi$ geometry with little or no surface features and modest vegetation. As previously mentioned, a rem meter was used to check the uniformity of the radiation field associated with the measurement site.

The conversion of the full absorption peak count rate to dose rate in air or activity per unit area on the ground depends upon the depth profile of the gamma emitter. For this reason, soil sample cores were collected from different depths. Subsequent laboratory analyses of the samples yields an inventory as well as relaxation mass per unit area. A more complete description of this technique can be found in the EML Procedures Manual, Section 3.3 (Chieco et al., 1992) and ICRU Report 53 (ICRU, 1994). 


\section{INSTRUMENT CALIBRATION}

The detector was calibrated for field operation using a collection of point sources obtained from the IAEA and the National Institute of Standards and Technology (NIST). The calibration procedures are detailed in the EML Procedures Manual, Section 3.3 (Chieco et al., 1992). As pointed out in the previous section, every effort was made to select sites which had a favorable source geometry. A counting time of 10 min usually gave a statistical uncertainty of no more than $10 \%$ for the peak count rate associated with

${ }^{137} \mathrm{Cs}$. The resulting concentrations for each of the natural emitters, and inventories for each of the various gamma emitters, ${ }^{137} \mathrm{Cs},{ }^{152} \mathrm{Eu}$, etc., can be converted to dose rate in air using the appropriate conversion factors (Beck, 1980; Beck et al., 1972). The individual dose rates can be added together with an appropriate value for the cosmic-ray contribution. The resulting dose rate can then be compared to PIC measurements. Total systematic errors related to detector calibration, soil parameters, and source geometry has been estimated to be no $>5 \%$. Agreement to within $5 \%$ indicates a good detector calibration, a suitable source geometry, and favorable soil conditions.

\section{RESULTS}

A summary of the absorbed dose rate in air calculated from the in situ analyses is shown in Table 2. Table 6 contains the inventory values for selected radionuclides obtained from the analyses of in situ gamma-ray spectra. Spectra from several locations were not analyzed either because dead-time losses and peak distortion from pulse pile-up could not be adequately compensated, or the source geometry was not appropriate to yield accurate inventory values. The principal gamma emitters detected varied with location. However, at all locations ${ }^{137} \mathrm{Cs}$ was detected along with peaks connected with the naturally occurring gamma emitters. Within a radius of about $13 \mathrm{~km}$ from historical ground zero $(5026.53 \mathrm{~N}, 77$ $48.877 \mathrm{E})$ the gamma emitters associated with ${ }^{152} \mathrm{Eu}$ and ${ }^{60} \mathrm{Co}$ were detected. Excessive dead-time losses and peak distortion from pulse pile-up, typically associated with high-radiation fields, were encountered within a $1 \mathrm{~km}$ radius around ground zero.

Table 7 summarizes the dose rate contribution from all gamma emitters to the total terrestrial dose rate. A cosmic component of $34.2 \mathrm{nGy} \mathrm{h}^{-1}$ was included to produce a dose rate that could be compared to measurements taken with a PIC. The value of the cosmic-ray component is based on geomagnetic latitude and altitude.

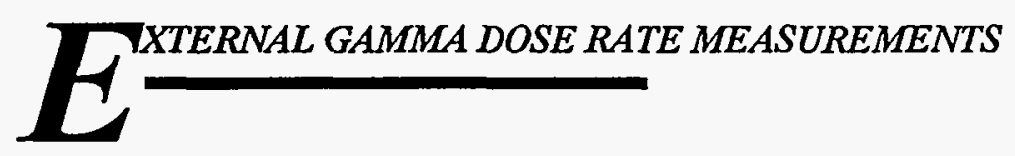

\section{METHODS}

The measurement of the external dose rate in air was conducted with an 18-cm diameter PIC which incorporates signal integration and digital readout display. A complete description of the instrument can be found in Latner et al. (1983). Measurements were conducted at $1 \mathrm{~m}$ above the ground. A series of at least five measurements, each consisting of a 40 s integration time, were obtained at each site, providing a standard error of $3 \%$ or less at the dose rate levels encountered. A more complete description of the PIC system can be found in the EML Procedures Manual, Section 3.2 (Chieco et al., 1992). 
Additionally, a Bicron Micro Rem Meter was used as a survey instrument to check for homogeneity in determining site selection. The detector, based on an internally mounted tissue-equivalent organic scintillator, provides the photon response from $0-200 \mathrm{mrem} \mathrm{h}^{-1}$ full scale with five linear ranges, and has a response time of $<15 \mathrm{~s}$. The energies of the gammas detected ranges from $\sim 40 \mathrm{keV}$ to $3 \mathrm{MeV}$.

\section{INSTRUMENT CALIBRATION}

Calibration of the PIC is performed with a sealed ${ }^{226} \mathrm{Ra}$ source certified by NIST in a shadow shield geometry. Conversion of exposure rate $\left(\mathrm{mR} \mathrm{h}^{-1}\right)$ to absorbed dose rate in air $\left(\mathrm{nGy} \mathrm{h}^{-1}\right)$ was made by multiplying by a factor of 8.76 . Although the PIC has a reasonably flat energy response, small corrections are applied to account for the different energy spectra of the primary beam calibration source and that of an environmental gamma-ray field. The total systematic error due to such factors as calibration and energy response is estimated to be $<5 \%$.

The Bicron Micro Rem Meter is calibrated with a NIST traceable $1 \mathrm{Ci}^{137} \mathrm{Cs}$ source, and is generally assumed to be accurate to within $20 \%$.

\section{RESULTS}

Table 2 summarizes the results of external dose rate determinations for the locations indicated. It should be pointed out that all things being equal, a determination of external dose rate is best accomplished with a PIC. Of the three methods used on this mission, a dose rate inferred from a soil sample is the least accurate and subject to the greatest uncertainties. Rem meters or survey instruments give an order of magnitude value for the dose rate, which, in several instances, was sufficient. While agreement among the various methods is generally good, there are some notable exceptions. At locations $725.2,725.3$, and 725.6 agreement between estimated dose rates from soil sampling and field spectrometric methods is excellent, but rather poor when compared to PIC measurements. We believe that the poor agreement is probably due to a malfunctioning of the PIC.

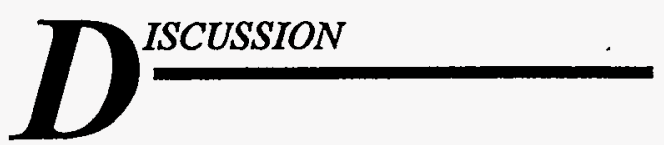

With the exception of the Lake Tchagan area and a $1 \mathrm{~km}^{2}$ area encompassing ground zero, all the areas visited by the team had external dose rates that were within typical environmental levels. However, both field spectrometry and soil samples have shown that the dose rate on a small farm $\sim 13 \mathrm{~km}$ from ground zero has been significantly enhanced by the presence of ${ }^{137} \mathrm{Cs},{ }^{152} \mathrm{Eu}$, and ${ }^{60} \mathrm{Co}$ in the surface soil. In this case, the contribution from these nuclides contribute about one-third of the terrestrial dose rate. Table 8 summarizes the primary contributors to the terrestrial dose rate from all anthropogenic sources for the typically inhabited areas visited on this mission. A typical range of the dose rate value currently used for global fallout is about $1-3 \mathrm{nGy} \mathrm{h}^{-1}$, this translates to about 1 to $5 \%$ of the total terrestrial dose rate. The results presented in Table 8 indicate that many of the towns visited are within the range of values that are typical of present global fallout.

The measurements taken within a $15 \mathrm{~km}$ radius of historical ground zero had elevated levels of ${ }^{137} \mathrm{Cs}$, as well as the activation products ${ }^{152} \mathrm{Eu}$, and ${ }^{60} \mathrm{Co}$. The dose rate within a $1 \mathrm{~km}$ radius of ground zero 
ranged from 500 to $30000 \mathrm{nGy} \mathrm{h}^{-1}$. The dose rate and the inventory of fission activation products decreased as we moved away from ground zero. At a distance of 20 to $25 \mathrm{~km}$ from ground zero, the enhancement of the ambient dose rate by ${ }^{137} \mathrm{Cs}$ is $<10 \%$ and contributions from ${ }^{152} \mathrm{Eu}$ and ${ }^{60} \mathrm{Co}$ were negligible. A location identified as a "hot spot" $\left(50^{\circ} 17.730^{\prime} \mathrm{N}, 77^{\circ} 57.989^{\prime} \mathrm{E}\right)$ from a previously performed aerial gamma survey was $\sim 20 \mathrm{~km}$ from ground zero. Soil cores, a field spectra, and a PIC measurement were taken and the results show that only ${ }^{137} \mathrm{Cs}$ could be detected and its contribution to the terrestrial dose is estimated at 1 to $2 \%$. It is interesting to note that near ground zero the radionuclide that dominates the dose rate is the activation product ${ }^{152} \mathrm{Eu}$. A soil sample taken approximately half a kilometer from ground zero indicated that ${ }^{152} \mathrm{Eu}$ contributes an estimated $76 \%$ of the total dose. Approximately $10 \mathrm{~km}$ from the location of that sample the contribution was down to just a few percent.

It should be carefully noted that the locations where our team performed measurements were supervised by officials. We observed several "technical areas," locations of which are shown in Figure 1, where the team did not perform measurements or take samples. It is quite possible that these areas may be radiologically stressed. Therefore, our samples and measurements can not be taken to be without bias, nor representative of the environmental contamination present at the Semipalatinsk nuclear test site. Additionally, with over 300 underground tests performed within the test site, the potential for groundwater contamination is a major concern. However, an assessment of the groundwater radioactivity was beyond the scope of the current team. Thus, assurances that the groundwater in the vicinity of the Semipalatinsk nuclear test site has not been radiologically contaminated have not been confirmed.

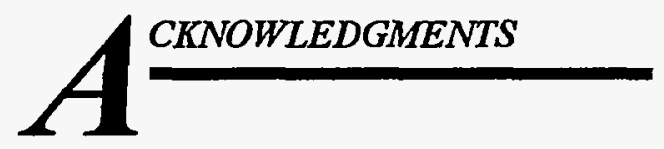

This report reflects an intensive effort, not only by the scientists who served on the mission, but also other EML staff members who contributed to different aspects of this project, to carry out rigorous field work and report such unique environmental data. The authors of this report are indebted to many EML staff members for their assistance in fulfilling this mission. We are especially grateful to Kevin Miller for guidance he provided over the course of the entire project. Mr. Kevin Clancy is thanked for administrative support. We are also grateful to Catherine Klusek and Richard Godwin for the preparation of the soil samples.

We thank EML Acting Director Philip W. Krey and Acting Deputy Director, Harold L. Beck, for their general support of this unique project. We also acknowledge the management staff at the DOE/Office of Health and Environmental Research for their support of this international project in joint Former Soviet Republics and American efforts.

Finally, we are grateful to the IAEA staff, particularly our team leader Dr. Peter Stegnar, our Kazak hosts in Kurchatov from the National Nuclear Center of the Republic of Kazakhstan and in Almaty from the Kazakhstan Atomic Energy Agency, and, of course, to the gracious residents of the villages we visited. 


\section{$\boldsymbol{R}^{\text {ziraneress }}$}

ASTM

"Soil Surface Soils for Radionuclides"

Annual Book of American Society of Testing Materials, C-998-83, Vol. 12.01, p. 792 (1983)

Beck, H. L.

"Exposure Rate Conversion Factors for Radionuclides Deposited on the Ground"

USDOE Report EML-378 (1980)

Beck, H. L., J. DeCampo and C. Gogolak

"In situ $\mathrm{Ge}(\mathrm{Li})$ and NaI(TI) Gamma-Ray Spectrometry"

USAEC Report HASL-258 (1972)

Chieco, N. A., D. C. Bogen, and E. O. Knutson, Eds.

"EML Procedures Manual"

USDOE Report HASL-300, 27th Edition, Vol. 1 (1992)

Debertin, K. and R. G. Helmer

Gamma- and X-Ray Spectrometry with Semiconductor Detectors

North-Holland (1988)

ICRU

"Gamma-Ray Spectrometry in the Environment"

International Commission on Radiation Units and Measurements, ICRU Report 53 (1994)

Latner, N., K. Miller, S. Watnick, R. T. Graveson

"SPICER: A Sensitive Radiation Survey Instrument"

Health Physics, 44, 379-386 (1983) 
TABLE 1

SITE IDENTIFICATION GEOGRAPHICAL POSITION (GPS), DESCRIPTION OF SITES, AND MEASUREMENTS OBTAINED USING PORTABLE IONIZATION CHAMBER (PIC), HIGH

PURITY IN SITU GAMMA SPECTROMETRY (HPGE), AND SOIL SAMPLES COLLECTED (SOIL)

\begin{tabular}{|c|c|c|c|c|c|}
\hline Site ID & GPS & Description & PIC & HPGe & Soil \\
\hline 718.1 & $50^{\circ} 38.469^{\prime} \mathrm{N}$ & Dolok, near ferry. Bare dirt, vegetation cover & * & & \\
\hline 718.2 & $\begin{array}{l}79^{\circ} 19.094^{\prime} \mathrm{E} \\
50^{\circ} 39.865^{\prime} \mathrm{N}\end{array}$ & $\begin{array}{l}0 \% \\
\text { Dolon, on side of main street. Bare dirt, }\end{array}$ & * & & \\
\hline 718.3 & $\begin{array}{l}79^{\circ} 18.355^{\prime} \mathrm{E} \\
50^{\circ} 40.034^{\prime} \mathrm{N}\end{array}$ & $\begin{array}{l}\text { vegetation cover } \sim 0 \% \\
\text { Dolon, across street from administrative building, }\end{array}$ & * & & \\
\hline 719.1 & $\begin{array}{l}79^{\circ} 18.542^{\prime} \mathrm{E} \\
49^{\circ} 56.326^{\prime} \mathrm{N}\end{array}$ & $\begin{array}{l}\text { over grass, vegetation cover } \sim 70 \% \\
\text { On lip of Balapan Lake ("Atomic Lake"). Zero }\end{array}$ & & * & * \\
\hline 719.2 & $\begin{array}{l}79^{\circ} 00.498^{\prime} E \\
49^{\circ} 56.577^{\prime} N\end{array}$ & $\begin{array}{l}\text { vegetation cover. HPGe taken, but not useful. } \\
\text { 1st State Farm Beriozka. In pasture, vegetation }\end{array}$ & * & * & * \\
\hline 719.3 & $\begin{array}{l}79^{\circ} 06.078^{\prime} \mathrm{E} \\
49^{\circ} 36.155^{\prime} \mathrm{N}\end{array}$ & $\begin{array}{l}\text { cover } \sim 50 \% \text {. } \\
\text { Sarzhal, center of town over dirt road. Vegetation }\end{array}$ & * & * & \\
\hline 720.1 & $\begin{array}{l}78^{\circ} 44.488^{\prime} \mathrm{E} \\
49^{\circ} 36.059^{\prime} \mathrm{N}\end{array}$ & $\begin{array}{l}\text { cover } \sim 0 \% . \\
\text { Sarzhal, edge of town in pasture. Vegetation }\end{array}$ & * & * & * \\
\hline 720.2 & $\begin{array}{l}78^{\circ} 44.981^{\prime} \mathrm{E} \\
49^{\circ} 36.330^{\prime} \mathrm{N}\end{array}$ & $\begin{array}{l}\text { cover } \sim 50 \% \text {. } \\
\text { Sarzhal, } 1 \mathrm{~km} \text { outside town in pasture. }\end{array}$ & * & * & * \\
\hline 720.3 & $\begin{array}{l}78^{\circ} 45.549^{\prime} \mathrm{E} \\
49^{\circ} 42.781^{\prime} \mathrm{N}\end{array}$ & $\begin{array}{l}\text { Vegetation cover } \sim 50 \% . \\
\sim 15 \mathrm{~km} \text { from Sarzhal at Project Plowshare }\end{array}$ & & & * \\
\hline 721.1 & $\begin{array}{l}78^{\circ} 27.817^{\prime} \mathrm{E} \\
49^{\circ} 12.638^{\prime} \mathrm{N}\end{array}$ & $\begin{array}{l}\text { "Excavation Lake" } \\
\text { Kainar, edge of town in pasture. Vegetation }\end{array}$ & * & * & * \\
\hline 721.2 & $\begin{array}{l}77^{\circ} 24.146^{\prime} \mathrm{E} \\
49^{\circ} 12.651^{\prime} \mathrm{N}\end{array}$ & $\begin{array}{l}\text { cover } \sim 100 \% . \\
\text { Kainar, near } 721.1, \text { drainage area for } 721.1 .\end{array}$ & * & * & * \\
\hline 721.3 & $\begin{array}{l}77^{\circ} 24.218^{\prime} \mathrm{E} \\
49^{\circ} 11.631^{\prime} \mathrm{N}\end{array}$ & $\begin{array}{l}\text { Vegetation cover } \sim 100 \% \\
\text { Kainar, opposite end of town in pasture. }\end{array}$ & * & * & \\
\hline 721.4 & $\begin{array}{l}77^{\circ} 23.891^{\prime} \mathrm{E} \\
49^{\circ} 29.707^{\prime} \mathrm{N}\end{array}$ & $\begin{array}{l}\text { Vegetation cover } \sim 100 \% \text {. } \\
\text { Near Polygon border, on ride back to Kurchatov. }\end{array}$ & * & * & \\
\hline 722.1 & $\begin{array}{l}77^{\circ} 35.983^{\prime} \mathrm{E} \\
50^{\circ} 48.007^{\prime} \mathrm{N}\end{array}$ & $\begin{array}{l}\text { Vegetation cover } \sim 100 \% . \\
\text { Akzhar, in the middle of town over dirt road. }\end{array}$ & * & & \\
\hline 722.2 & $\begin{array}{l}78^{\circ} 28.089^{\prime} \mathrm{E} \\
50^{\circ} 47.678^{\prime} \mathrm{N}\end{array}$ & $\begin{array}{l}\text { Vegetation cover } \sim 0 \% \text {. } \\
\text { Akzhar, edge of town in pasture. Vegetation }\end{array}$ & * & & * \\
\hline 725.1 & $\begin{array}{l}78^{\circ} 26.886^{\prime} \mathrm{E} \\
50^{\circ} 26.110^{\prime} \mathrm{N}\end{array}$ & $\begin{array}{l}\text { cover } \sim 50 \% . \\
\sim 0.5 \mathrm{~km} \text { from } \mathrm{GZ} . \text { In field, vegetation cover } \sim\end{array}$ & & * & \\
\hline 725.2 & $\begin{array}{l}77^{\circ} 48.966^{\prime} \mathrm{E} \\
50^{\circ} 25.810^{\prime} \mathrm{N}\end{array}$ & $\begin{array}{l}50 \% \text {. } \\
1.1 \mathrm{~km} \text { south of } \mathrm{GZ} \text {. Field, } \sim 50 \% \text { vegetation }\end{array}$ & * & * & * \\
\hline & & & & & \\
\hline
\end{tabular}


TABLE 1 (Cont'd)

\begin{tabular}{|c|c|c|c|c|c|}
\hline Site ID & GPS & Description & PIC & HPGe & Soil \\
\hline 725.3 & $50^{\circ} 26.766^{\prime} \mathrm{N}$ & $1.1 \mathrm{~km}$ north of GZ. Field $\sim 50 \%$ vegetation & * & - & * \\
\hline 725.4 & $\begin{array}{l}77^{\circ} 48.359^{\prime} \mathrm{E} \\
50^{\circ} 25.129^{\prime} \mathrm{N}\end{array}$ & $\begin{array}{l}\text { cover. } \\
\sim 3 \mathrm{~km} \text { from } \mathrm{GZ} \text {, surveyed with PIC and Bicron. }\end{array}$ & & * & \\
\hline 725.5 & $\begin{array}{l}77^{\circ} 50.675^{\prime} \mathrm{E} \\
50^{\circ} 24.799^{\prime} \mathrm{N}\end{array}$ & $\begin{array}{l}\text { Vegetation cover } \sim 50 \% \text {. } \\
\sim 4 \mathrm{~km} \text { from } \mathrm{GZ} \text {, at site sampled by American }\end{array}$ & * & * & \\
\hline 725.6 & $\begin{array}{l}77^{\circ} 51.188^{\prime} E \\
50^{\circ} 21.898^{\prime} N\end{array}$ & $\begin{array}{l}\text { team. Vegetation cover } \sim 50 \% \text {. } \\
\text { Near plume, vegetation cover } \sim 70 \% \text {. }\end{array}$ & * & * & * \\
\hline 726.GZ & $\begin{array}{l}77^{\circ} 50.660^{\prime} \mathrm{E} \\
50^{\circ} 26.230^{\prime} \mathrm{N}\end{array}$ & $200 \mathrm{~m}$ from Ground Zero & & & * \\
\hline 726.1 & $\begin{array}{l}77^{\circ} 48.986^{\prime} \mathrm{E} \\
50^{\circ} 17.730^{\prime} \mathrm{N}\end{array}$ & "Hot spot" as indicated by maps provided. & * & * & * \\
\hline 726.2 & $\begin{array}{l}77^{\circ} 57.989^{\prime} \mathrm{E} \\
50^{\circ} 19.433^{\prime} \mathrm{N}\end{array}$ & $\begin{array}{l}\text { Vegetation cover } \sim 50 \% \text {. } \\
\text { At farm near another indicated "hot spot." } \sim 13 \mathrm{~km}\end{array}$ & * & * & \\
\hline 727.1 & $\begin{array}{l}77^{\circ} 49.457^{\prime} \mathrm{E} \\
50^{\circ} 39.976^{\prime} \mathrm{N}\end{array}$ & $\begin{array}{l}\text { from GZ. Vegetation cover } \sim 20 \% . \\
\text { Outside Dolon, in pasture. Vegetation cover }\end{array}$ & * & * & * \\
\hline 727.2 & $\begin{array}{l}79^{\circ} 17.833^{\prime} \mathrm{E} \\
50^{\circ} 40.034^{\prime} \mathrm{N}\end{array}$ & $\begin{array}{l}50 \% . \\
\text { In Dolon, in middle of dirt street. Vegetation cover }\end{array}$ & * & * & \\
\hline & $79^{\circ} 18.542^{\prime} \mathrm{E}$ & $\sim 0 \%$ & & & \\
\hline
\end{tabular}


TABLE 2

ABSORBED DOSE RATES IN AIR (nGy $\left.h^{-1}\right)$

\begin{tabular}{|c|c|c|c|c|}
\hline Site ID & PIC & $\begin{array}{l}\text { In-situ } \\
\text { Spectra }\end{array}$ & Soil Sample & Other \\
\hline 718.1 & $72(1)$ & - & - & \\
\hline 718.2 & $69(10)$ & - & - & \\
\hline 718.3 & $59(4)$ & - & - & \\
\hline 719.1 & - & - & - & 13100 (survey meter) \\
\hline 719.2 & $77(3)$ & $92(1)$ & $84(1)$ & \\
\hline 719.3 & $82(2)$ & - & - & \\
\hline 720.1 & $90(5)$ & $96(1)$ & $96(1)$ & \\
\hline 720.2 & $87(2)$ & $96(1)$ & $95(1)$ & \\
\hline 721.1 & $112(4)$ & $111(1)$ & $120(1)$ & \\
\hline 721.2 & $81(4)$ & $73(1)$ & $71(1)$ & \\
\hline 721.3 & $107(5)$ & $114(1)$ & - & \\
\hline 721.4 & $89(3)$ & $96(01)$ & - & \\
\hline 722.1 & $77(6)$ & - & - & \\
\hline 722.2 & $81(2)$ & - & $92(1)$ & \\
\hline 725.1 & - & - & - & 32000 (survey meter) \\
\hline 725.2 & $120(7)$ & $138(3)$ & $140(1)$ & \\
\hline 725.3 & $112(2)$ & $149(3)$ & 153(1) & \\
\hline 725.4 & - & $118(3)$ & - & \\
\hline 725.5 & $93(5)$ & - & - & \\
\hline 725.6 & $94(9)$ & $117(2)$ & $121(1)$ & \\
\hline 726.1 & $87(4)$ & - & $92(1)$ & \\
\hline $726.1 a$ & - & - & $13700(28)$ & 12000 (survey meter) \\
\hline 726.2 & $104(5)$ & $118(4)$ & - & \\
\hline 727.1 & $91(2)$ & $97(1)$ & $89(1)$ & \\
\hline 727.2 & $93(4)$ & - & - & \\
\hline
\end{tabular}




\section{TABLE 3}

SOIL SAMPLE DATA AND RADIONUCLIDE CONCENTRATION (Bq kg $\left.{ }^{-1} \mathrm{dry}\right)$

EML ID Depth Wet wgt. Dry wgt. Dry density Nuclide Concentration $1 \sigma$ $(\mathrm{cm})$

(g)

(g) $\quad(\mathrm{g} / \mathrm{cc})$

$\left(B q k^{-1} d r y\right)$

719.1 Area of soil core $\left(\mathrm{cm}^{2}\right)=46.5$ :

\begin{tabular}{|c|c|c|c|c|c|c|c|}
\hline \multirow[t]{5}{*}{ S-4264 } & $0-5$ & 1413.5 & 1341.8 & 1.62 & $\begin{array}{c}{ }^{241} \mathrm{Am} \\
{ }^{152} \mathrm{Eu}\end{array}$ & $\begin{array}{l}450.9 \\
8791\end{array}$ & $\begin{array}{c}3 \\
68\end{array}$ \\
\hline & & & & & ${ }^{154} \mathrm{Eu}$ & 4027 & 35 \\
\hline & & & & & ${ }^{155} \mathrm{Eu}$ & 146.9 & 4.1 \\
\hline & & 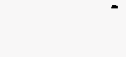 & & & ${ }^{60} \mathrm{Co}$ & 6829 & 13 \\
\hline & & & & & ${ }^{137} \mathrm{Cs}$ & 7805 & 8 \\
\hline \multirow[t]{6}{*}{ S-4265 } & $5-10$ & 826.2 & 776.7 & 1.70 & ${ }^{241} \mathrm{Am}$ & 1056 & 2 \\
\hline & & & & & ${ }^{152} \mathrm{Eu}$ & 28198 & 52 \\
\hline & & & & & ${ }^{154} \mathrm{Eu}$ & 16156 & 44 \\
\hline & & & & & ${ }^{155} \mathrm{Eu}$ & 586.0 & 4.9 \\
\hline & & & & & ${ }^{60} \mathrm{Co}$ & 27554 & 17 \\
\hline & & & & & ${ }^{137} \mathrm{Cs}$ & 24783 & 15 \\
\hline \multirow[t]{6}{*}{ S-4266 } & $10-15$ & 827.5 & 775.2 & 1.70 & ${ }^{241} \mathrm{Am}$ & 669.3 & 2 \\
\hline & & & & & ${ }^{152} \mathrm{Eu}$ & 16898 & 65 \\
\hline & & & & & ${ }^{154} \mathrm{Eu}$ & 11431 & 54 \\
\hline & & & & & ${ }^{155} \mathrm{Eu}$ & 393.9 & 5.5 \\
\hline & & & & & ${ }^{60} \mathrm{Co}$ & 21836 & 27 \\
\hline & & & & & ${ }^{137} \mathrm{Cs}$ & 21549 & 15 \\
\hline
\end{tabular}

719.2 Area of soil core $\left(\mathrm{cm}^{2}\right)=46.5$ :

\begin{tabular}{|c|c|c|c|c|c|c|c|}
\hline \multirow[t]{4}{*}{ S-4267 } & $0-5$ & 726.2 & 723.7 & 1.44 & ${ }^{226} \mathrm{Ra}$ & 24.24 & 0.52 \\
\hline & & & & & ${ }^{228} \mathrm{Ra}$ & 17.87 & 0.70 \\
\hline & & & & & ${ }^{40} \mathrm{~K}$ & 684.5 & 7.4 \\
\hline & & & & & ${ }^{137} \mathrm{Cs}$ & 6.9 & 0.3 \\
\hline \multirow[t]{4}{*}{ S-4268 } & $5-10$ & 1097.5 & 963.0 & 1.51 & ${ }^{226} \mathrm{Ra}$ & 25.57 & 0.48 \\
\hline & & & & & ${ }^{228} \mathrm{Ra}$ & 20.42 & 0.67 \\
\hline & & & & & ${ }^{40} \mathrm{~K}$ & 662.3 & 7.8 \\
\hline & & & , & & ${ }^{137} \mathrm{Cs}$ & ND MDC 0.07 & - \\
\hline \multirow[t]{4}{*}{ S-4269 } & $10-15$ & 1117.7 & 1041.7 & 1.49 & ${ }^{226} \mathrm{Ra}$ & 24.94 & 0.48 \\
\hline & & & & & ${ }^{228} \mathrm{Ra}$ & 21.09 & 0.67 \\
\hline & & & & & ${ }^{40} \mathrm{~K}$ & 636.4 & 7.4 \\
\hline & & & & & ${ }^{137} \mathrm{Cs}$ & 0.518 & 0.148 \\
\hline
\end{tabular}


TABLE 3 (Cont'd)

EML ID Depth Wet wgt. Drywgt. Dry density Nuclide Concentration $1 \sigma$
(cm)
(g)
(g) $\quad(g / c c)$
(Bq kg-1 dry)

720.1 Area of soil core $\left(\mathrm{cm}^{2}\right)=46.5$ :

\begin{tabular}{|c|c|c|c|c|c|c|c|}
\hline \multirow[t]{3}{*}{ S-4270 } & $0-5$ & 539.6 & 497.5 & 1.21 & $\begin{array}{l}{ }^{226} \mathrm{Ra} \\
{ }^{228} \mathrm{Ra}\end{array}$ & $\begin{array}{l}33.49 \\
26.90\end{array}$ & $\begin{array}{l}0.67 \\
0.89\end{array}$ \\
\hline & & & & & ${ }^{40} \mathrm{~K}$ & 651.2 & 8.9 \\
\hline & & & & & ${ }^{137} \mathrm{Cs}$ & 72.15 & 0.74 \\
\hline \multirow[t]{4}{*}{$S-4271$} & $5-10$ & 852.1 & 805.3 & 1.34 & ${ }^{226} \mathrm{Ra}$ & 32.56 & 0.96 \\
\hline & & & & & ${ }^{228} \mathrm{Ra}$ & 26.97 & 1.33 \\
\hline & & & & & ${ }^{40} \mathrm{~K}$ & 710.4 & 14.8 \\
\hline & & & & & ${ }^{137} \mathrm{Cs}$ & 19.98 & 0.74 \\
\hline \multirow[t]{4}{*}{ S-4272 } & $10-15$ & 982.0 & 923.4 & 1.45 & ${ }^{226} \mathrm{Ra}$ & 32.26 & 0.52 \\
\hline & & & & & ${ }^{228} \mathrm{Ra}$ & 23.72 & 0.74 \\
\hline & & & & & ${ }^{40} \mathrm{~K}$ & 673.4 & 7 \\
\hline & & & & & ${ }^{137} \mathrm{Cs}$ & 2.220 & 0.370 \\
\hline \multirow[t]{4}{*}{ S-4273 } & $15-30$ & 1369.8 & 1267.3 & 1.52 & ${ }^{226} \mathrm{Ra}$ & 27.97 & 0.63 \\
\hline & & & & & ${ }^{228} \mathrm{Ra}$ & 23.64 & 0.85 \\
\hline & & & & & ${ }^{40} \mathrm{~K}$ & 658.6 & 11.1 \\
\hline & & & & & ${ }^{137} \mathrm{Cs}$ & 3.811 & 0.259 \\
\hline
\end{tabular}

720.2 Area of soil core $\left(\mathrm{cm}^{2}\right)=46.5$

\begin{tabular}{|c|c|c|c|c|c|c|c|}
\hline \multirow[t]{3}{*}{$S-4274$} & $0-5$ & 575.6 & 541.9 & 1.17 & $\begin{array}{l}{ }^{226} \mathrm{Ra} \\
{ }^{228} \mathrm{Ra}\end{array}$ & $\begin{array}{l}24.24 \\
17.87\end{array}$ & $\begin{array}{l}0.52 \\
0.70\end{array}$ \\
\hline & & & & & ${ }^{40} \mathrm{~K}$ & 684.5 & 7.4 \\
\hline & & & & & ${ }^{137} \mathrm{Cs}$ & 6.882 & 0.296 \\
\hline \multirow[t]{4}{*}{$S-4275$} & $5-10$ & 697.3 & 643.0 & 1.09 & ${ }^{226} \mathrm{Ra}$ & 25.57 & 0.48 \\
\hline & & & & & ${ }^{228} \mathrm{Ra}$ & 20.42 & 0.67 \\
\hline & & & & & ${ }^{40} \mathrm{~K}$ & 662.3 & 7.8 \\
\hline & & & & & ${ }^{137} \mathrm{Cs}$ & ND MDC 0.7 & - \\
\hline \multirow[t]{4}{*}{ S-4276 } & $10-15$ & 800.9 & 718.3 & 1.29 & ${ }^{226} \mathrm{Ra}$ & 24.94 & 0.48 \\
\hline & & & & & ${ }^{228} \mathrm{Ra}$ & 21.09 & 0.67 \\
\hline & & & & & ${ }^{40} \mathrm{~K}$ & 636 & 7 \\
\hline & & & & & ${ }^{137} \mathrm{Cs}$ & 0.518 & 0.148 \\
\hline
\end{tabular}


TABLE 3 (Cont'd)

EML ID Depth Wet wgt. Dry wgt. Dry density Nuclide Concentration $1 \sigma$
$(\mathrm{cm})$
(g)
(g)
$(\mathrm{g} / \mathrm{cc})$
$\left(B q \mathrm{~kg}^{-1} \mathrm{dry}\right)$

720.3 Area of soil core $\left(\mathrm{cm}^{2}\right)=\mathrm{NA}$

$\begin{array}{lllllllc}\text { S-4277 NA } & \text { NA } & \text { NA } & 1.38 & { }^{241} \mathrm{Am} & 315774 & 37 \\ & & & & { }^{239} \mathrm{Pu} & 2371930 & 207400\end{array}$

721.1 Area of soil core $\left(\mathrm{cm}^{2}\right)=46.5$ :

\begin{tabular}{|c|c|c|c|c|c|c|c|}
\hline \multirow[t]{4}{*}{ S-42.79 } & $0-5$ & 642.3 & 609.0 & 1.22 & ${ }^{226} \mathrm{Ra}$ & 43.03 & 0.59 \\
\hline & & & & & ${ }^{228} \mathrm{Ra}$ & 40.81 & 0.81 \\
\hline & & & & & ${ }^{40} \mathrm{~K}$ & 913.5 & 8.8 \\
\hline & & & & & ${ }^{137} \mathrm{Cs}$ & 19.35 & 0.37 \\
\hline \multirow[t]{4}{*}{ S-4280 } & $5-10$ & 737.1 & 672.0 & 1.16 & ${ }^{226} \mathrm{Ra}$ & 44.47 & 0.26 \\
\hline & & & & & ${ }^{228} \mathrm{Ra}$ & 43.51 & 0.37 \\
\hline & & & & & ${ }^{40} \mathrm{~K}$ & 977.2 & 4.1 \\
\hline & & & & & ${ }^{137} \mathrm{Cs}$ & 3.70 & 0.111 \\
\hline \multirow[t]{4}{*}{ S-4281 } & $10-15$ & 814.8 & 754.9 & 1.10 & ${ }^{226} \mathrm{Ra}$ & 45.58 & 0.63 \\
\hline & & & & & ${ }^{228} \mathrm{Ra}$ & 44.14 & 0.93 \\
\hline & & & & & ${ }^{40} \mathrm{~K}$ & 954.2 & 9.6 \\
\hline & & & & & ${ }^{137} \mathrm{Cs}$ & 1.036 & 0.222 \\
\hline
\end{tabular}

721.2 Area of soil core $\left(\mathrm{cm}^{2}\right)=46.5$ :

\begin{tabular}{|c|c|c|c|c|c|c|c|}
\hline \multirow[t]{4}{*}{ S-4282 } & $0-5$ & 482.3 & 284.9 & 0.71 & ${ }^{226} \mathrm{Ra}$ & 33.86 & 0.48 \\
\hline & & & & & ${ }^{228} \mathrm{Ra}$ & 29.42 & 0.70 \\
\hline & & & & & ${ }^{40} \mathrm{~K}$ & 427.4 & 5.9 \\
\hline & & & & & ${ }^{137} \mathrm{Cs}$ & 51.43 & 0.44 \\
\hline \multirow[t]{4}{*}{ S-4283 } & $5-10$ & 520.8 & 267.5 & 0.60 & ${ }^{226} \mathrm{Ra}$ & 35.00 & 0.63 \\
\hline & & & & & ${ }^{228} \mathrm{Ra}$ & 27.12 & 0.93 \\
\hline & & & & & ${ }^{40} \mathrm{~K}$ & 384.1 & 7.5 \\
\hline & & & & & ${ }^{137} \mathrm{Cs}$ & 2.368 & 0.259 \\
\hline \multirow[t]{4}{*}{ S-4284 } & $10-15$ & 632.6 & 383.4 & 0.78 & ${ }^{226} \mathrm{Ra}$ & 44.77 & 0.37 \\
\hline & & & & & ${ }^{228} \mathrm{Ra}$ & 38.48 & 0.48 \\
\hline & & & & & ${ }^{40} \mathrm{~K}$ & 493.2 & 4.0 \\
\hline & & & & & ${ }^{137} \mathrm{Cs}$ & 0.999 & 0.148 \\
\hline
\end{tabular}


TABLE 3 (Cont'd)

EML ID Depth Wet wgt. Drywgt. Dry density Nuclide Concentration 10
(cm)
(g)
(g) $\quad(g / c c)$
(Bq kg-1 dry)

722.2 Area of soil core $\left(\mathrm{cm}^{2}\right)=46.5$ :

\begin{tabular}{|c|c|c|c|c|c|c|c|}
\hline \multirow{4}{*}{ S-4285 } & $0-5$ & 666.2 & 643.2 & 1.47 & ${ }^{226} \mathrm{Ra}$ & 26.38 & 0.52 \\
\hline & & & & & ${ }^{228} \mathrm{Ra}$ & 25.49 & 0.67 \\
\hline & & & & & ${ }^{40} \mathrm{~K}$ & 734.1 & 8.1 \\
\hline & & & & & ${ }^{137} \mathrm{Cs}$ & 12.91 & 0.30 \\
\hline \multirow[t]{4}{*}{ S-4286 } & $5-10$ & 862.6 & 834.9 & 1.41 & ${ }^{226} \mathrm{Ra}$ & 25.97 & 0.52 \\
\hline & & & & & ${ }^{228} \mathrm{Ra}$ & 23.90 & 0.70 \\
\hline & & & & & ${ }^{40} \mathrm{~K}$ & 720.4 & 8.3 \\
\hline & & & & & ${ }^{137} \mathrm{Cs}$ & 1.073 & 0.185 \\
\hline \multirow[t]{3}{*}{ S-4287 } & $10-15$ & 926.7 & 895.3 & 1.42 & ${ }^{226} \mathrm{Ra}$ & 25.83 & 0.52 \\
\hline & & & & & ${ }^{228} \mathrm{Ra}$ & 25.90 & 0.70 \\
\hline & & & & & $\begin{array}{c}{ }^{40} \mathrm{~K} \\
{ }^{137} \mathrm{C}\end{array}$ & $\begin{array}{l}715.2 \\
1036\end{array}$ & 8.1 \\
\hline
\end{tabular}

725.2 Area of soil core $\left(\mathrm{cm}^{2}\right)=46.5$ :

\begin{tabular}{|c|c|c|c|c|c|c|c|}
\hline \multirow[t]{8}{*}{$S-4288$} & $0-5$ & 720.1 & 693.9 & 1.65 & ${ }^{226} \mathrm{Ra}$ & 40.70 & 0.74 \\
\hline & & & & & ${ }^{228} \mathrm{Ra}$ & 26.01 & 0.85 \\
\hline & & & & & ${ }^{40} \mathrm{~K}$ & 654.9 & 8.5 \\
\hline & & & & & ${ }^{137} \mathrm{Cs}$ & 257.2 & 1.1 \\
\hline & & & & & ${ }^{152} \mathrm{Eu}$ & 18.13 & 1.85 \\
\hline & & & & & ${ }^{155} \mathrm{Eu}$ & 0.888 & 0.259 \\
\hline & & & & & ${ }^{241} \mathrm{Am}$ & 290.8 & 1.5 \\
\hline & & & & & ${ }^{60} \mathrm{Co}$ & 4.070 & 0.370 \\
\hline \multirow[t]{8}{*}{$S-4289$} & $5-10$ & 757.0 & 729.2 & 1.50 & ${ }^{226} \mathrm{Ra}$ & 32.75 & 0.48 \\
\hline & & & & & ${ }^{228} \mathrm{Ra}$ & 24.49 & 0.63 \\
\hline & & & & & ${ }^{40} \mathrm{~K}$ & 640.1 & 8.5 \\
\hline & & & & & ${ }^{137} \mathrm{Cs}$ & 19.24 & 0.37 \\
\hline & & & & & ${ }^{152} \mathrm{Eu}$ & 7.77 & 1.11 \\
\hline & & & & & ${ }^{155} \mathrm{Eu}$ & ND MDC 1.1 & - \\
\hline & & & & & ${ }^{241} \mathrm{Am}$ & 10.14 & 0.22 \\
\hline & & & & & ${ }^{60} \mathrm{Co}$ & 0.888 & 0.222 \\
\hline
\end{tabular}


TABLE 3 (Cont'd)

\begin{tabular}{|c|c|c|c|c|c|c|c|}
\hline EML ID & $\begin{array}{l}\text { Depth } \\
(\mathrm{cm})\end{array}$ & $\begin{array}{c}\text { Wet wgt. } \\
\text { (g) }\end{array}$ & $\begin{array}{c}\text { Dry wgt. } \\
\text { (g) }\end{array}$ & $\begin{array}{l}\text { Dry density } \\
\qquad(\mathrm{g} / \mathrm{cc})\end{array}$ & Nuclide & \multicolumn{2}{|c|}{$\left(B q k^{-1}\right.$ dry $)$} \\
\hline 725.2 & \multicolumn{3}{|c|}{ (continued) } & & & & \\
\hline \multirow[t]{8}{*}{ S-4290 } & $10-15$ & 899.0 & 860.4 & 1.58 & ${ }^{226} \mathrm{Ra}$ & 20.31 & 0.26 \\
\hline & & & & & ${ }^{228} \mathrm{Ra}$ & 26.12 & 0.04 \\
\hline & . & & & & ${ }^{40} \mathrm{~K}$ & 647.5 & 4.1 \\
\hline & & & & & ${ }^{137} \mathrm{Cs}$ & 4.440 & 0.740 \\
\hline & & & & & ${ }^{152} \mathrm{Eu}$ & ND MDC 3.3 & - \\
\hline & & & & & ${ }^{155} \mathrm{Eu}$ & ND MDC 0.74 & - \\
\hline & & & & & ${ }^{241} \mathrm{Am}$ & 3.108 & 0.111 \\
\hline & & & & & ${ }^{60} \mathrm{Co}$ & ND MDC 0.11 & - \\
\hline
\end{tabular}

725.3 Area of soil core $\left(\mathrm{cm}^{2}\right)=46.5$ :

\begin{tabular}{|c|c|c|c|c|c|c|c|}
\hline \multirow[t]{7}{*}{ S-4291 } & $0-5$ & 681.5 & 664.0 & 1.65 & $\begin{array}{l}{ }^{226} \mathrm{Ra} \\
{ }^{228} \mathrm{Ra}\end{array}$ & $\begin{array}{l}25.83 \\
28.12\end{array}$ & $\begin{array}{l}2.44 \\
0.67\end{array}$ \\
\hline & & & & & ${ }^{40} \mathrm{~K}$ & 677.1 & 6.7 \\
\hline & & & & & ${ }^{137} \mathrm{Cs}$ & 334.5 & 1.1 \\
\hline & & & & & ${ }^{152} \mathrm{Eu}$ & 62.53 & 3.33 \\
\hline & & & & & ${ }^{155} \mathrm{Eu}$ & 5.291 & 0.259 \\
\hline & & & & & ${ }^{241} \mathrm{Am}$ & 173.2 & 0.7 \\
\hline & & & & & ${ }^{60} \mathrm{Co}$ & 5.254 & 0.407 \\
\hline \multirow[t]{8}{*}{ S-4292 } & $5-10$ & 897.0 & 859.4 & 1.44 & ${ }^{226} \mathrm{Ra}$ & 29.05 & 2.22 \\
\hline & & & & & ${ }^{228} \mathrm{Ra}$ & 29.60 & 0.56 \\
\hline & & & & & ${ }^{40} \mathrm{~K}$ & 666.4 & 5.9 \\
\hline & & & & & ${ }^{137} \mathrm{Cs}$ & 62.16 & 0.37 \\
\hline & & & & & ${ }^{152} \mathrm{Eu}$ & 18.87 & 2.59 \\
\hline & & & & & ${ }^{155} \mathrm{Eu}$ & 3.959 & 0.259 \\
\hline & & & & & ${ }^{241} \mathrm{Am}$ & 11.84 & 0.37 \\
\hline & & & & & ${ }^{60} \mathrm{Co}$ & 1.258 & 0.222 \\
\hline
\end{tabular}


TABLE 3 (Cont'd)

EML ID Depth Wet wgt. Drywgt. Dry density Nuclide Concentration 10

$\begin{array}{lllll}(\mathrm{cm}) & (\mathrm{g}) \quad(\mathrm{g}) & (\mathrm{g} / \mathrm{cc}) & (\mathrm{Bq} \mathrm{kg}) & \mathrm{dry})\end{array}$

725.3 (continued)

\begin{tabular}{llll}
\hline$-4293 \quad 10-15$ & 812.1 & 773.0
\end{tabular}

1.32

$\begin{array}{ccc}{ }^{226} \mathrm{Ra} & 29.97 & 1.48 \\ { }^{228} \mathrm{Ra} & 29.56 & 0.41 \\ { }^{40} \mathrm{~K} & 696 & 4 \\ { }^{137} \mathrm{Cs} & 18.43 & 0.22 \\ { }^{152} \mathrm{Eu} & 14.80 & 0.74 \\ { }^{155} \mathrm{Eu} & 0.37 & 0.07 \\ { }^{241} \mathrm{Am} & 1.665 & 0.111 \\ { }^{60} \mathrm{Co} & 0.814 & 0.185\end{array}$

725.6 Area of soil core $\left(\mathrm{cm}^{2}\right)=46.5$ :

\begin{tabular}{|c|c|c|c|c|c|c|c|}
\hline \multirow[t]{8}{*}{ S-4294 } & $0-5$ & 577.6 & 563.8 & 1.33 & ${ }^{226} \mathrm{Ra}$ & 49.95 & 0.74 \\
\hline & & & & & ${ }^{228} \mathrm{Ra}$ & 28.27 & 0.85 \\
\hline & & & & & ${ }^{40} \mathrm{~K}$ & 699.3 & 8.5 \\
\hline & & & & & ${ }^{137} \mathrm{Cs}$ & 162.8 & 1.1 \\
\hline & & & & & ${ }^{152} \mathrm{Eu}$ & 4.810 & 1.110 \\
\hline & & & & & ${ }^{155} \mathrm{Eu}$ & 2.183 & 0.222 \\
\hline & & & & & ${ }^{241} \mathrm{Am}$ & 110.6 & 0.8 \\
\hline & & & & & ${ }^{60} \mathrm{Co}$ & 1.258 & 0.185 \\
\hline \multirow[t]{8}{*}{ S-4295 } & $5-10$ & 739.2 & 685.2 & 1.13 & ${ }^{226} \mathrm{Ra}$ & 58.46 & 0.93 \\
\hline & & & & & ${ }^{228} \mathrm{Ra}$ & 30.64 & 0.74 \\
\hline & & & & & ${ }^{40} \mathrm{~K}$ & 795.5 & 9.6 \\
\hline & & & & & ${ }^{137} \mathrm{Cs}$ & 9.361 & 0.333 \\
\hline & & & & & ${ }^{152} \mathrm{Eu}$ & ND MDC 6.6 & - \\
\hline & & & & & ${ }^{155} \mathrm{Eu}$ & 0.629 & 0.185 \\
\hline & & & & & ${ }^{241} \mathrm{Am}$ & 6.512 & 0.296 \\
\hline & & & & & ${ }^{60} \mathrm{Co}$ & ND MDC 0.55 & - \\
\hline
\end{tabular}


TABLE 3 (Cont'd)

\begin{tabular}{|c|c|c|c|c|c|c|c|}
\hline EML ID & $\begin{array}{l}\text { Depth } \\
(\mathrm{cm})\end{array}$ & $\begin{array}{l}\text { Wet wgt. } \\
\text { (g) }\end{array}$ & $\begin{array}{l}\text { Dry wgt. } \\
\text { (g) }\end{array}$ & $\begin{array}{l}\text { Dry density } \\
\text { (g/cc) }\end{array}$ & Nuclide & \multicolumn{2}{|c|}{$\left(B q k^{-1} \mathrm{dry}\right)$} \\
\hline 725.6 & \multicolumn{3}{|c|}{ (continued) } & & & & \\
\hline \multirow[t]{8}{*}{ S-4296 } & \multirow[t]{8}{*}{$10-15$} & \multirow[t]{8}{*}{792.5} & \multirow[t]{8}{*}{717.2} & \multirow[t]{8}{*}{1.14} & ${ }^{226} \mathrm{Ra}$ & 58.09 & 0.33 \\
\hline & & & & & ${ }^{228} \mathrm{Ra}$ & 28.97 & 0.37 \\
\hline & & & & & ${ }^{40} \mathrm{~K}$ & 747.4 & 4.4 \\
\hline & & & & & ${ }^{137} \mathrm{Cs}$ & 4.033 & 0.185 \\
\hline & & & & & ${ }^{152} \mathrm{Eu}$ & ND MDC 3 & - \\
\hline & & & & & ${ }^{155} \mathrm{Eu}$ & 0.481 & 0.185 \\
\hline & & & & & ${ }^{241} \mathrm{Am}$ & 3.071 & 0.111 \\
\hline & & & & & ${ }^{60} \mathrm{Co}$ & ND MDC 0.3 & - \\
\hline 726.GZ & \multicolumn{3}{|c|}{ Area of soil core $\left(\mathrm{cm}^{2}\right)=62.0$ : } & & & & \\
\hline \multirow[t]{9}{*}{ S-4297 } & \multirow[t]{9}{*}{$0-5$} & \multirow[t]{9}{*}{880.1} & \multirow[t]{9}{*}{838.9} & \multirow[t]{9}{*}{1.58} & ${ }^{226} \mathrm{Ra}$ & 20.05 & 2.70 \\
\hline & & & & & ${ }^{228} \mathrm{Ra}$ & 58.46 & 1.48 \\
\hline & & & & & ${ }^{40} \mathrm{~K}$ & 773.3 & 18.5 \\
\hline & & & & & ${ }^{137} \mathrm{Cs}$ & 24205 & 100 \\
\hline & & & & & ${ }^{152} \mathrm{Eu}$ & 39220 & 185 \\
\hline & & & & & ${ }^{154} \mathrm{Eu}$ & 1109 & 25 \\
\hline & & & & & ${ }^{155} \mathrm{Eu}$ & 365.2 & 20.0 \\
\hline & & & & & ${ }^{241} \mathrm{Am}$ & 435.9 & 3.3 \\
\hline & & & & & ${ }^{60} \mathrm{Co}$ & 1650 & 7 \\
\hline \multirow[t]{9}{*}{ S-4298 } & \multirow[t]{9}{*}{$5-10$} & \multirow[t]{9}{*}{963.3} & \multirow[t]{9}{*}{914.3} & \multirow[t]{9}{*}{1.45} & ${ }^{226} \mathrm{Ra}$ & 24.20 & 1.48 \\
\hline & & & & & ${ }^{228} \mathrm{Ra}$ & 31.19 & 2.07 \\
\hline & & & & & ${ }^{40} \mathrm{~K}$ & 758.5 & 7.4 \\
\hline & & & & & ${ }^{137} \mathrm{Cs}$ & 2980 & 21 \\
\hline & & & & & ${ }^{152} \mathrm{Eu}$ & 30118 & 148 \\
\hline & & & & & ${ }^{154} \mathrm{Eu}$ & 679.3 & 24.8 \\
\hline & & & & & ${ }^{155} \mathrm{Eu}$ & 35.52 & 4.81 \\
\hline & & & & & ${ }^{241} \mathrm{Am}$ & 61.05 & 2.59 \\
\hline & & & & & ${ }^{60} \mathrm{Co}$ & 1100 & 9 \\
\hline
\end{tabular}


TABLE 3 (Cont'd)

EML ID Depth Wet wgt. Dry wgt. Dry density Nuclide Concentration 10 $\begin{array}{lllll}(\mathrm{cm}) & (\mathrm{g}) \quad(\mathrm{g}) & (\mathrm{g} / \mathrm{cc}) & (\mathrm{Bq} / \mathrm{kg}-\mathrm{dry})\end{array}$

\begin{tabular}{|c|c|c|c|c|c|c|c|}
\hline 726.GZ & (continu & & & & & & \\
\hline \multirow[t]{9}{*}{ S-4299 } & $10-15$ & 1282.7 & 1192.7 & 1.51 & ${ }^{226} \mathrm{Ra}$ & 25.01 & 1.26 \\
\hline & & & & & ${ }^{228} \mathrm{Ra}$ & 29.01 & 2.22 \\
\hline & & & & & ${ }^{40} \mathrm{~K}$ & 466.2 & 7.4 \\
\hline & & & & & ${ }^{137} \mathrm{Cs}$ & 1534 & 13 \\
\hline & & & & & ${ }^{152} \mathrm{Eu}$ & 19610 & 37 \\
\hline & & & & & ${ }^{154} \mathrm{Eu}$ & 311.2 & 11.5 \\
\hline & & & & & ${ }^{155} \mathrm{Eu}$ & 27.38 & 4.4 \\
\hline & & & & & ${ }^{241} \mathrm{Am}$ & 24.79 & 1.48 \\
\hline & & & & & ${ }^{60} \mathrm{Co}$ & 691.2 & 4.8 \\
\hline
\end{tabular}

726.1 Area of soil core $\left(\mathrm{cm}^{2}\right)=46.5$ :

\begin{tabular}{|c|c|c|c|c|c|c|c|}
\hline \multirow[t]{4}{*}{$S-4300$} & $0-5$ & 367.6 & 361.4 & 1.50 & ${ }^{226} \mathrm{Ra}$ & 44.84 & 0.07 \\
\hline & & & & & ${ }^{228} \mathrm{Ra}$ & 22.42 & 0.74 \\
\hline & & & & & ${ }^{40} \mathrm{~K}$ & 584.6 & 7.4 \\
\hline & & & & & ${ }^{137} \mathrm{Cs}$ & 18.61 & 0 \\
\hline \multirow[t]{4}{*}{$S-4301$} & $5-10$ & 551.5 & 521.1 & 1.24 & ${ }^{226} \mathrm{Ra}$ & 44.70 & 0.07 \\
\hline & & & & & ${ }^{228} \mathrm{Ra}$ & 19.68 & 0.07 \\
\hline & & & & & ${ }^{40} \mathrm{~K}$ & 642.0 & 8.5 \\
\hline & & & & & ${ }^{137} \mathrm{Cs}$ & 3.811 & 0.259 \\
\hline \multirow[t]{4}{*}{ S-4302 } & $10-15$ & 526.4 & 468.0 & 1.21 & ${ }^{226} \mathrm{Ra}$ & 46.36 & 0.07 \\
\hline & & & & & ${ }^{228} \mathrm{Ra}$ & 18.91 & 0.07 \\
\hline & & & & & ${ }^{40} \mathrm{~K}$ & 605.0 & 7.8 \\
\hline & & & & & ${ }^{137} \mathrm{Cs}$ & 1.369 & 0.370 \\
\hline
\end{tabular}


TABLE 3 (Cont'd)

\begin{tabular}{|c|c|c|c|c|c|c|c|}
\hline EML ID & $\begin{array}{l}\text { Depth } \\
(\mathrm{cm})\end{array}$ & $\begin{array}{l}\text { Wet wgt. } \\
\text { (g) }\end{array}$ & $\begin{array}{l}\text { Dry wgt. } \\
\text { (g) }\end{array}$ & $\begin{array}{l}\text { Dry density } \\
\text { (g/cc) }\end{array}$ & Nuclide & $\begin{array}{l}\text { Concentration } \\
\qquad\left(\mathrm{Bq} \mathrm{kg}{ }^{-1} \mathrm{dry}\right)\end{array}$ & 10 \\
\hline 727.1 & \multicolumn{7}{|c|}{ Area of soil core $\left(\mathrm{cm}^{2}\right)=46.5$ : } \\
\hline \multirow[t]{4}{*}{ S-4303 } & 0.5 & 455.7 & 448.4 & 1.58 & ${ }^{226} \mathrm{Ra}$ & 20.05 & 0.49 \\
\hline & & & & & ${ }^{228} \mathrm{Ra}$ & 23.09 & 0.67 \\
\hline & & & & & ${ }^{40} \mathrm{~K}$ & 700.4 & 8.0 \\
\hline & & & & & ${ }^{137} \mathrm{Cs}$ & 47.51 & 0.52 \\
\hline \multirow[t]{4}{*}{ S-4304 } & $5-10$ & 472.7 & 457.6 & 1.59 & ${ }^{226} \mathrm{Ra}$ & 18.39 & 0.33 \\
\hline & & & & & ${ }^{228} \mathrm{Ra}$ & 20.61 & 0.48 \\
\hline & & & & & ${ }^{40} \mathrm{~K}$ & 721.9 & 5.9 \\
\hline & & & & & ${ }^{137} \mathrm{Cs}$ & 31.15 & 3 \\
\hline \multirow[t]{4}{*}{ S-4305 } & $10-15$ & 634.1 & 604.4 & 1.60 & ${ }^{226} \mathrm{Ra}$ & 17.87 & 0.22 \\
\hline & & & & & ${ }^{228} \mathrm{Ra}$ & 20.50 & 0.33 \\
\hline & & & & & ${ }^{40} \mathrm{~K}$ & 709.3 & 4.1 \\
\hline & & & & & ${ }^{137} \mathrm{Cs}$ & 21.16 & 1.85 \\
\hline
\end{tabular}


TABLE 4

INFERRED RADIONUCLIDE INVENTORY $\left(\mathrm{kBq} \mathrm{m}^{-2}\right)$

FROM SOIL SAMPLES

\begin{tabular}{|c|c|c|c|c|}
\hline $\begin{array}{l}\text { Location } \\
\text { ID }\end{array}$ & Nuclide & $\begin{array}{l}\text { Relaxation mass } \\
\text { per unit area } \\
\left(\mathrm{g} \mathrm{cm}^{-2}\right)\end{array}$ & $\begin{array}{l}\text { Inventory } \\
\left(\mathrm{kBq} \mathrm{m}^{-2}\right)\end{array}$ & $\begin{array}{c}S D \\
\left(k B q m^{-2}\right)\end{array}$ \\
\hline 719.2 & ${ }^{137} \mathrm{Cs}$ & 8.55 & 1.31 & 0.10 \\
\hline 720.1 & ${ }^{137} \mathrm{Cs}$ & 6.71 & 6.32 & 0.09 \\
\hline 720.2 & ${ }^{137} \mathrm{Cs}$ & 5.88 & 4.23 & 0.24 \\
\hline 721.1 & ${ }^{137} \mathrm{Cs}$ & 9.17 & 3.24 & 0.06 \\
\hline 721.2 & ${ }^{137} \mathrm{Cs}$ & 3.85 & 3.37 & 0.03 \\
\hline 722.2 & ${ }^{137} \mathrm{Cs}$ & 11.8 & 2.18 & 0.06 \\
\hline \multirow[t]{5}{*}{725.2} & ${ }^{137} \mathrm{Cs}$ & 6.25 & 42.1 & 0.2 \\
\hline & ${ }^{152} \mathrm{Eu}$ & 16.7 & 10.7 & 0.5 \\
\hline & ${ }^{155} \mathrm{Eu}$ & 29.4 & 0.44 & 0.23 \\
\hline & ${ }^{241} \mathrm{Am}$ & 5.08 & 45.5 & 0.2 \\
\hline & ${ }^{60} \mathrm{Co}$ & 9.62 & 0.77 & 0.07 \\
\hline \multirow[t]{5}{*}{725.3} & ${ }^{137} \mathrm{Cs}$ & 10.0 & 61.7 & 0.2 \\
\hline & ${ }^{152} \mathrm{Eu}$ & 18.9 & 14.9 & 0.7 \\
\hline & ${ }^{155} \mathrm{Eu}$ & 21.7 & 1.55 & 0.09 \\
\hline & ${ }^{241} \mathrm{Am}$ & 6.10 & 27.2 & 0.1 \\
\hline & ${ }^{60} \mathrm{Co}$ & 15.2 & 1.12 & 0.08 \\
\hline \multirow[t]{5}{*}{725.6} & ${ }^{137} \mathrm{Cs}$ & 6.67 & 21.7 & 0.1 \\
\hline & ${ }^{152} \mathrm{Eu}$ & 20.4 & 2.02 & 1.09 \\
\hline & ${ }^{155} \mathrm{Eu}$ & 15.2 & 0.43 & 0.05 \\
\hline & ${ }^{241} \mathrm{Am}$ & 5.32 & 14.9 & 0.1 \\
\hline & ${ }^{60} \mathrm{Co}$ & 14.9 & 0.27 & 0.09 \\
\hline \multirow[t]{6}{*}{ 726.GZ } & ${ }^{137} \mathrm{Cs}$ & 10.3 & 4010 & 14 \\
\hline & ${ }^{152} \mathrm{Eu}$ & 23.3 & 13500 & 34 \\
\hline & ${ }^{154} \mathrm{Eu}$ & 18.9 & 310 & 5 \\
\hline & ${ }^{155} \mathrm{Eu}$ & 6.10 & 54.7 & 2.8 \\
\hline & ${ }^{241} \mathrm{Am}$ & 9.52 & 67.7 & 0.6 \\
\hline & ${ }^{60} \mathrm{Co}$ & 22.2 & 555 & 2 \\
\hline 726.1 & ${ }^{137} \mathrm{Cs}$ & 5.41 & 1.87 & 0.03 \\
\hline 727.1 & ${ }^{137} \mathrm{Cs}$ & 15.6 & 10.4 & 0.41 \\
\hline
\end{tabular}


TABLE 5

INFERRED ABSORBED DOSE RATES IN AIR BY

NUCLIDE $\left(n \mathrm{ny} \mathrm{h}^{-1}\right)$ FROM SOIL SAMPLES

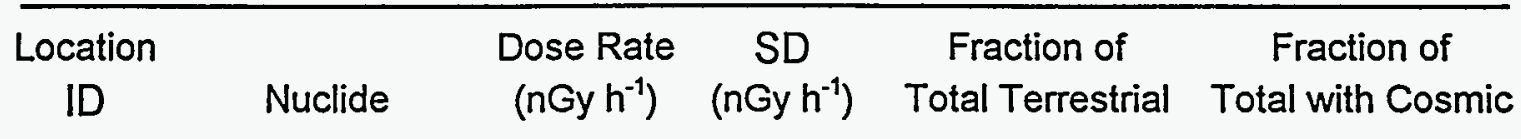

719.2

$\begin{array}{rcccc}{ }^{226} \mathrm{Ra} & 9.76 & 0.33 & 0.20 & 0.12 \\ { }^{228} \mathrm{Ra} & 12.51 & 0.47 & 0.25 & 0.15 \\ { }^{40} \mathrm{~K} & 26.42 & 0.55 & 0.53 & 0.31 \\ { }^{137} \mathrm{Cs} & 1.17 & 0.12 & 0.02 & 0.01\end{array}$

Total Terrestrial $\quad 49.85 \quad 0.81$

Total with cosmic $\quad 84.02$

720.1

$\begin{array}{rrrrr}{ }^{226} \mathrm{Ra} & 12.61 & 0.57 & 0.20 & 0.13 \\ { }^{228} \mathrm{Ra} & 15.59 & 0.78 & 0.25 & 0.16 \\ { }^{40} \mathrm{~K} & 28.36 & 0.61 & 0.46 & 0.30 \\ { }^{137} \mathrm{Cs} & 5.32 & 0.14 & 0.09 & 0.06\end{array}$

$\begin{array}{lll}\text { Total Terrestrial } & 61.88 & 1.15\end{array}$

Total with Cosmic 96.04

720.2

$\begin{array}{rrrrr}{ }^{226} \mathrm{Ra} & 13.54 & 0.56 & 0.22 & 0.14 \\ { }^{228} \mathrm{Ra} & 16.74 & 0.77 & 0.28 & 0.18 \\ { }^{40} \mathrm{~K} & 24.78 & 0.78 & 0.41 & 0.26 \\ { }^{137} \mathrm{Cs} & 5.23 & 0.17 & 0.09 & 0.06\end{array}$

Total Terrestrial $\quad 60.28 \quad 1.24$

Total with Cosmic 94.45

721.1

$\begin{array}{rrrrr}{ }^{226} \mathrm{Ra} & 17.74 & 0.36 & 0.21 & 0.15 \\ { }^{228} \mathrm{Ra} & 27.03 & 0.51 & 0.31 & 0.22 \\ { }^{40} \mathrm{~K} & 38.32 & 0.54 & 0.45 & 0.32 \\ { }^{137} \mathrm{Cs} & 2.88 & 0.16 & 0.03 & 0.02\end{array}$

$\begin{array}{lll}\text { Total Terrestrial } \quad 85.96 & 0.84\end{array}$

Total with Cosmic 120.13 
'TABLE 5 (Cont'd)

\begin{tabular}{|c|c|c|c|c|c|}
\hline $\begin{array}{l}\text { Location } \\
\text { ID }\end{array}$ & Nuclide & $\begin{array}{l}\text { Dose Rate } \\
\left(n G y h^{-1}\right)\end{array}$ & $\begin{array}{c}S D \\
\left(n G y h^{-1}\right)\end{array}$ & $\begin{array}{c}\text { Fraction of } \\
\text { Total Terrestrial }\end{array}$ & $\begin{array}{c}\text { Fraction of } \\
\text { Total with Cosmic }\end{array}$ \\
\hline
\end{tabular}

721.2

$\begin{array}{rrrrr}{ }^{226} \mathrm{Ra} & 9.77 & 0.21 & 0.27 & 0.14 \\ { }^{228} \mathrm{Ra} & 13.26 & 0.30 & 0.36 & 0.19 \\ { }^{40} \mathrm{~K} & 11.26 & 0.24 & 0.31 & 0.16 \\ { }^{137} \mathrm{Cs} & 2.14 & 0.10 & 0.06 & 0.03\end{array}$

Total Terrestrial $36.43 \quad 0.45$

Total with Cosmic $\quad 70.60$

722.2

$\begin{array}{rrrrr}{ }^{226} \mathrm{Ra} & 10.75 & 0.37 & 0.22 & 0.13 \\ { }^{228} \mathrm{Ra} & 16.23 & 0.49 & 0.33 & 0.19 \\ { }^{40} \mathrm{~K} & 29.66 & 0.58 & 0.59 & 0.35 \\ { }^{137} \mathrm{Cs} & 1.46 & 0.09 & 0.03 & 0.02\end{array}$

$\begin{array}{lll}\text { Total Terrestrial } & 58.09 & 0.85\end{array}$

Total with Cosmic $\quad 92.25$

725.2

$\begin{array}{rrlll}{ }^{226} \mathrm{Ra} & 10.19 & 0.38 & 0.10 & 0.07 \\ { }^{228} \mathrm{Ra} & 16.70 & 0.47 & 0.16 & 0.12 \\ { }^{40} \mathrm{~K} & 26.68 & 0.48 & 0.25 & 0.19 \\ { }^{137} \mathrm{Cs} & 37.33 & 0.38 & 0.35 & 0.27 \\ { }^{152} \mathrm{Eu} & 10.90 & 0.53 & 0.10 & 0.078 \\ { }^{155} \mathrm{Eu} & 0.01 & 0.01 & <.0001 & <.0001 \\ { }^{241} \mathrm{Am} & 1.32 & 0.007 & 0.012 & 0.009 \\ { }^{60} \mathrm{Co} & 2.41 & 0.210 & 0.023 & 0.017\end{array}$

Total Terrestrial $105.56 \quad 1.03$

Total with Cosmic ${ }^{\dagger} \quad 139.7$

${ }^{\dagger}$ Cosmic dose rate 
TABLE 5 (Cont'd)

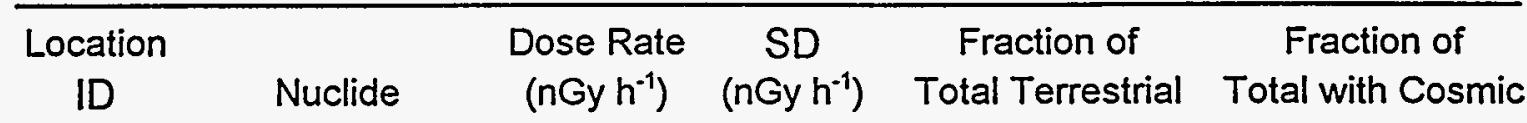

725.3

$\begin{array}{rrlll}{ }^{226} \mathrm{Ra} & 13.38 & 0.22 & 0.11 & 0.09 \\ { }^{228} \mathrm{Ra} & 19.75 & 0.23 & 0.17 & 0.13 \\ { }^{40} \mathrm{~K} & 27.71 & 0.30 & 0.23 & 0.18 \\ { }^{137} \mathrm{Cs} & 41.08 & 0.59 & 0.34 & 0.27 \\ { }^{152} \mathrm{Eu} & 13.80 & 0.63 & 0.12 & 0.09 \\ { }^{155} \mathrm{Eu} & 0.07 & 0.009 & <.0001 & <.0001 \\ { }^{241} \mathrm{Am} & 0.72 & 0.001 & 0.006 & 0.005 \\ { }^{60} \mathrm{Co} & 2.71 & 0.189 & 0.023 & 0.018\end{array}$

Total Terrestrial $119.2 \quad 1.0$

Total with Cosmic 153.4

725.6

$\begin{array}{rllll}{ }^{226} \mathrm{Ra} & 22.48 & 0.44 & 0.26 & 0.19 \\ { }^{228} \mathrm{Ra} & 17.77 & 0.45 & 0.20 & 0.15 \\ { }^{40} \mathrm{~K} & 29.09 & 0.54 & 0.33 & 0.24 \\ { }^{137} \mathrm{Cs} & 14.85 & 0.23 & 0.17 & 0.12 \\ { }^{152} \mathrm{Eu} & 1.76 & 0.95 & 0.020 & 0.014 \\ { }^{155} \mathrm{Eu} & 0.024 & 0.003 & <.0001 & <.0001 \\ { }^{241} \mathrm{Am} & 0.42 & 0.003 & 0.005 & <.0001 \\ { }^{60} \mathrm{Co} & 0.67 & 0.227 & 0.008 & 0.006\end{array}$

Total Terrestrial $\quad 87.06 \quad 1.30$

Total with Cosmic 121.2

726.GZ

$\begin{array}{rrrll}{ }^{226} \mathrm{Ra} & 8.55 & 1.15 & 0.001 & 0.001 \\ { }^{228} \mathrm{Ra} & 39.03 & 0.99 & 0.003 & 0.003 \\ { }^{40} \mathrm{~K} & 32.77 & 0.78 & 0.002 & 0.002 \\ { }^{137} \mathrm{Cs} & 2943 & 10 & 0.22 & 0.21 \\ { }^{152} \mathrm{Eu} 10434 & 26 & 0.76 & 0.76 \\ { }^{155} \mathrm{Eu} & 14.5 & 0.3 & 0.001 & 0.001 \\ { }^{241} \mathrm{Am} & 1.46 & 0.07 & <.0001 & <.0001 \\ { }^{60} \mathrm{Co} & 214.4 & 2.0 & 0.02 & 0.02\end{array}$

Total Terrestrial $13688 \quad 28$

Total with Cosmic 13722 
TABLE 5 (Cont'd)

\begin{tabular}{|c|c|c|c|c|c|}
\hline $\begin{array}{l}\text { Location } \\
\text { ID }\end{array}$ & Nuclide & $\begin{array}{c}\text { Dose Rate } \\
\left(n G y h^{-1}\right)\end{array}$ & $\begin{array}{c}S D \\
\left(n G y h^{-1}\right)\end{array}$ & $\begin{array}{c}\text { Fraction of } \\
\text { Total Terrestrial }\end{array}$ & $\begin{array}{c}\text { Fraction of } \\
\text { Total with Cosmic }\end{array}$ \\
\hline \multicolumn{6}{|l|}{726.1} \\
\hline & ${ }^{226} \mathrm{Ra}$ & 18.39 & 0.45 & 0.32 & 0.20 \\
\hline & ${ }^{228} \mathrm{Ra}$ & 13.59 & 0.44 & 0.24 & 0.15 \\
\hline & ${ }^{40} \mathrm{~K}$ & 24.96 & 0.46 & 0.43 & 0.27 \\
\hline & ${ }^{137} \mathrm{Cs}$ & 0.80 & 0.16 & 0.01 & 0.01 \\
\hline & Total Terrestrial & 57.75 & 0.79 & & \\
\hline & Total with Cosmic & 91.91 & & & \\
\hline \multicolumn{6}{|l|}{727.1} \\
\hline & ${ }^{226} \mathrm{Ra}$ & 7.48 & 0.26 & 0.14 & 0.08 \\
\hline & ${ }^{228} \mathrm{Ra}$ & 13.41 & 1.02 & 0.24 & 0.15 \\
\hline & ${ }^{40} \mathrm{~K}$ & 28.99 & 0.44 & 0.53 & 0.32 \\
\hline & ${ }^{137} \mathrm{Cs}$ & 5.16 & 0.56 & 0.09 & 0.06 \\
\hline & Total Terrestrial & 55.04 & 1.27 & & \\
\hline & Total with Cosmic & 89.21 & & & \\
\hline
\end{tabular}

${ }^{\dagger}$ Cosmic Dose rate 
TABLE 6

RADIONUCLIDE INVENTORY (KBq $\mathrm{m}^{-2}$ ) FROM IN SITU SPECTRA

\begin{tabular}{ccccc}
\hline $\begin{array}{c}\text { Location } \\
\text { ID }\end{array}$ & Nuclide & $\begin{array}{c}\text { Relaxation mass } \\
\text { per unit area } \\
\left(\mathrm{g} \mathrm{cm}^{-2}\right)\end{array}$ & $\begin{array}{c}\text { (nventory } \\
\left(\mathrm{kBq} \mathrm{m}^{-2}\right)\end{array}$ & $\begin{array}{c}\text { SD } \\
\left(\mathrm{kBq} \mathrm{m} \mathrm{m}^{-2}\right)\end{array}$ \\
\hline 719.2 & ${ }^{137} \mathrm{Cs}$ & 8.55 & 1.47 & 0.09 \\
720.1 & ${ }^{137} \mathrm{Cs}$ & 6.71 & 5.96 & 0.17 \\
720.2 & ${ }^{137} \mathrm{Cs}$ & 5.88 & 5.55 & 0.21 \\
721.1 & ${ }^{137} \mathrm{Cs}$ & 9.17 & 3.75 & 0.23 \\
721.2 & ${ }^{137} \mathrm{Cs}$ & 3.85 & 1.93 & 0.09 \\
721.3 & ${ }^{137} \mathrm{Cs}$ & $6.67^{\dagger}$ & 3.90 & 0.79 \\
721.4 & ${ }^{137} \mathrm{Cs}$ & $6.67^{\dagger}$ & 4.97 & 1.00 \\
725.2 & ${ }^{137} \mathrm{Cs}$ & 6.25 & 40.7 & 0.4 \\
& ${ }^{152} \mathrm{Eu}$ & 16.7 & 13.8 & 2.4 \\
& ${ }^{60} \mathrm{Co}$ & 9.62 & 0.53 & 0.18 \\
725.3 & ${ }^{137} \mathrm{Cs}$ & 10.0 & 56.1 & 1.7 \\
& ${ }^{152} \mathrm{Eu}$ & 18.9 & 13.3 & 1.70 \\
& ${ }^{60} \mathrm{Co}$ & 15.2 & 1.47 & 0.20 \\
725.5 & ${ }^{137} \mathrm{Cs}$ & $7.69^{\dagger}$ & 27.2 & 4.1 \\
& ${ }^{152} \mathrm{Eu}$ & $13.2^{\dagger}$ & 4.95 & 1.53 \\
& ${ }^{60} \mathrm{Co}$ & $16.9^{\dagger}$ & 0.53 & 0.12 \\
725.6 & ${ }^{137} \mathrm{Cs}$ & 5.26 & 15.1 & 0.1 \\
& ${ }^{152} \mathrm{Eu}$ & 20.4 & 2.36 & 1.79 \\
& ${ }^{60} \mathrm{Co}$ & 14.9 & 0.31 & 0.13 \\
726.1 & ${ }^{137} \mathrm{Cs}$ & 5.41 & 0.83 & 0.17 \\
726.2 & ${ }^{137} \mathrm{Cs}$ & $6.67^{\dagger}$ & 25.4 & 0.3 \\
& ${ }^{152} \mathrm{Eu}$ & $13.2^{\dagger}$ & 3.16 & 1.66 \\
727.1 & ${ }^{60} \mathrm{Co}$ & $16.9^{\dagger}$ & 0.53 & 0.18 \\
& ${ }^{137} \mathrm{Cs}$ & 15.6 & 9.31 & 1.68 \\
\hline
\end{tabular}

${ }^{\dagger}$ Estimated 
TABLE 7

ABSORBED DOSE RATES IN AIR BY NUCLIDE (nGy $h^{-1}$ )

FROM IN SITU SPECTRA

\begin{tabular}{|c|c|c|c|c|c|}
\hline $\begin{array}{l}\text { Location } \\
\text { ID }\end{array}$ & Nuclide & $\begin{array}{l}\text { Dose Rate } \\
\left(n G y h^{-1}\right)\end{array}$ & $\begin{array}{c}S D \\
\left(n G y h^{-1}\right)\end{array}$ & $\begin{array}{c}\text { Fraction of } \\
\text { Total Terrestrial }\end{array}$ & $\begin{array}{c}\text { Fraction of } \\
\text { Total with Cosmic }\end{array}$ \\
\hline
\end{tabular}

719.2

$\begin{array}{rrrrr}{ }^{226} \mathrm{Ra} & 13.14 & 0.35 & 0.23 & 0.14 \\ { }^{228} \mathrm{Ra} & 15.94 & 0.70 & 0.28 & 0.17 \\ { }^{40} \mathrm{~K} & 27.68 & 1.14 & 0.48 & 0.30 \\ { }^{137} \mathrm{Cs} & 1.17 & 0.12 & 0.02 & 0.01\end{array}$

Total Terrestrial $57.93 \quad 1.39$

Total with Cosmic ${ }^{\dagger} \quad 92.10$

720.1

$\begin{array}{rrrrr}{ }^{226} \mathrm{Ra} & 14.28 & 0.44 & 0.23 & 0.15 \\ { }^{228} \mathrm{Ra} & 16.29 & 0.70 & 0.26 & 0.17 \\ { }^{40} \mathrm{~K} & 25.75 & 0.70 & 0.42 & 0.27 \\ { }^{137} \mathrm{Cs} & 5.32 & 0.14 & 0.09 & 0.06\end{array}$

Total Terrestrial $\quad 61.65 \quad 1.09$

Total with Cosmic 95.81

720.2

$\begin{array}{rrrrr}{ }^{226} \mathrm{Ra} & 13.49 & 0.35 & 0.22 & 0.14 \\ { }^{228} \mathrm{Ra} & 17.43 & 0.61 & 0.28 & 0.18 \\ { }^{40} \mathrm{~K} & 25.67 & 5.26 & 0.42 & 0.27 \\ { }^{137} \mathrm{Cs} & 5.23 & 0.17 & 0.08 & 0.05\end{array}$

Total Terrestrial $\quad 61.82 \quad 5.31$

Total with Cosmic 95.98

721.1

$\begin{array}{rrrrr}{ }^{226} \mathrm{Ra} & 15.94 & 0.44 & 0.21 & 0.14 \\ { }^{228} \mathrm{Ra} & 23.91 & 0.70 & 0.31 & 0.22 \\ { }^{40} \mathrm{~K} & 34.25 & 0.70 & 0.44 & 0.31 \\ { }^{137} \mathrm{Cs} & 2.88 & 0.16 & 0.04 & 0.03\end{array}$

Total Terrestrial $76.99 \quad 1.10$

Total with Cosmic 111.15 
TABLE 7 (Cont'd)

\begin{tabular}{|c|c|c|c|c|c|}
\hline $\begin{array}{l}\text { Location } \\
\text { ID }\end{array}$ & Nuclide & $\begin{array}{c}\text { Dose Rate } \\
\left(n G y h^{-1}\right)\end{array}$ & $\begin{array}{c}S D \\
\left(n G y h^{-1}\right)\end{array}$ & $\begin{array}{c}\text { Fraction of } \\
\text { Total Terrestrial }\end{array}$ & $\begin{array}{c}\text { Fraction of } \\
\text { Total with Cosmic }\end{array}$ \\
\hline
\end{tabular}

721.2

$\begin{array}{rrrrr}{ }^{226} \mathrm{Ra} & 9.64 & 0.35 & 0.25 & 0.13 \\ { }^{228} \mathrm{Ra} & 14.28 & 0.53 & 0.37 & 0.20 \\ { }^{40} \mathrm{~K} & 12.61 & 0.44 & 0.33 & 0.17 \\ { }^{137} \mathrm{Cs} & 2.14 & 0.10 & 0.06 & 0.03\end{array}$

$\begin{array}{lll}\text { Total Terrestrial } & 38.67 & 0.77\end{array}$

Total with Cosmic $\quad 72.83$

721.3

$\begin{array}{rrrrr}{ }^{226} \mathrm{Ra} & 15.59 & 0.44 & 0.19 & 0.14 \\ { }^{228} \mathrm{Ra} & 24.79 & 0.70 & 0.31 & 0.22 \\ { }^{40} \mathrm{~K} & 36.27 & 0.44 & 0.45 & 0.32 \\ { }^{137} \mathrm{Cs} & 3.48 & 0.53 & 0.04 & 0.03\end{array}$

Total Terrestrial $80.13 \quad 1.08$

Total with Cosmic 114.29

721.4

$\begin{array}{rrrrr}{ }^{226} \mathrm{Ra} & 15.68 & 0.26 & 0.25 & 0.16 \\ { }^{228} \mathrm{Ra} & 16.82 & 0.53 & 0.27 & 0.17 \\ { }^{40} \mathrm{~K} & 25.05 & 0.44 & 0.40 & 0.26 \\ { }^{137} \mathrm{Cs} & 4.44 & 0.67 & 0.07 & 0.05\end{array}$

$\begin{array}{lll}\text { Total Terrestrial } \quad 61.99 & 0.99\end{array}$

Total with Cosmic $\quad 96.16$

725.2

$\begin{array}{rrrrr}{ }^{226} \mathrm{Ra} & 10.16 & 0.35 & 0.10 & 0.07 \\ { }^{228} \mathrm{Ra} & 15.68 & 0.61 & 0.15 & 0.11 \\ { }^{40} \mathrm{~K} & 24.27 & 0.53 & 0.23 & 0.18 \\ { }^{137} \mathrm{Cs} & 37.33 & 0.38 & 0.36 & 0.27 \\ { }^{152} \mathrm{Eu} & 13.86 & 2.41 & 0.13 & 0.10 \\ { }^{60} \mathrm{Co} & 2.91 & 0.48 & 0.03 & 0.02\end{array}$

Total Terrestrial $104.20 \quad 2.64$

Total with Cosmic $^{\dagger} \quad 138.4$ 
TABLE 7 (Cont'd)

\begin{tabular}{|c|c|c|c|c|c|}
\hline $\begin{array}{l}\text { Location } \\
\quad \text { ID }\end{array}$ & Nuclide & $\begin{array}{c}\text { Dose Rate } \\
\left(n G y h^{-1}\right)\end{array}$ & $\begin{array}{c}S D \\
\left(n G y h^{-1}\right)\end{array}$ & $\begin{array}{c}\text { Fraction of } \\
\text { Total Terrestrial }\end{array}$ & $\begin{array}{c}\text { Fraction of } \\
\text { Total with Cosmic }\end{array}$ \\
\hline \multicolumn{6}{|l|}{725.3} \\
\hline & ${ }^{226} \mathrm{Ra}$ & 10.95 & 0.37 & 0.10 & 0.07 \\
\hline & ${ }^{228} \mathrm{Ra}$ & 20.06 & 0.62 & 0.17 & 0.13 \\
\hline & ${ }^{40} \mathrm{~K}$ & 27.24 & 0.58 & 0.24 & 0.18 \\
\hline & ${ }^{137} \mathrm{Cs}$ & 41.08 & 0.59 & 0.36 & 0.28 \\
\hline & ${ }^{152} \mathrm{Eu}$ & 12.20 & 2.41 & 0.11 & 0.08 \\
\hline & ${ }^{60} \mathrm{Co}$ & 3.51 & 0.627 & 0.03 & 0.02 \\
\hline & $\begin{array}{l}\text { Total Terrestrial } \\
\text { Total with Cosmic }\end{array}$ & $\begin{array}{l}115.0 \\
149.2\end{array}$ & 2.7 & & \\
\hline
\end{tabular}

725.5

$\begin{array}{rrrrr}{ }^{226} \mathrm{Ra} & 11.83 & 0.35 & 0.14 & 0.10 \\ { }^{228} \mathrm{Ra} & 17.26 & 0.61 & 0.21 & 0.15 \\ { }^{40} \mathrm{~K} & 25.67 & 0.61 & 0.31 & .0 .22 \\ { }^{137} \mathrm{Cs} & 22.77 & 2.50 & 0.27 & 0.19 \\ { }^{152} \mathrm{Eu} & 4.98 & 1.54 & 0.06 & 0.04 \\ { }^{60} \mathrm{Co} & 1.41 & 0.38 & 0.02 & 0.01\end{array}$

Total Terrestrial $83.90 \quad 3.10$

Total with Cosmic 118.1

725.6

$\begin{array}{rrrrr}{ }^{226} \mathrm{Ra} & 17.70 & 0.44 & 0.21 & 0.15 \\ { }^{228} \mathrm{Ra} & 18.92 & 0.61 & 0.23 & 0.16 \\ { }^{40} \mathrm{~K} & 28.21 & 0.61 & 0.34 & 0.24 \\ { }^{137} \mathrm{Cs} & 14.85 & 0.23 & 0.18 & 0.13 \\ { }^{152} \mathrm{Eu} & 2.37 & 1.80 & 0.03 & 0.02 \\ { }^{60} \mathrm{Co} & 0.82 & 0.40 & 0.01 & 0.01\end{array}$

Total Terrestrial $\quad 82.86 \quad 2.10$

Total with Cosmic 117.0 
TABLE 7 (Cont'd)

\begin{tabular}{|c|c|c|c|c|c|}
\hline $\begin{array}{l}\text { Location } \\
\text { ID }\end{array}$ & Nuclide & $\begin{array}{l}\text { Dose Rate } \\
\left(n G y h^{-1}\right)\end{array}$ & $\begin{array}{l}\text { SD } \\
\left(n G y h^{-1}\right)\end{array}$ & $\begin{array}{c}\text { Fraction of } \\
\text { Total Terrestrial }\end{array}$ & $\begin{array}{c}\text { Fraction of } \\
\text { Total with Cosmic }\end{array}$ \\
\hline \multicolumn{6}{|l|}{726.1} \\
\hline & ${ }^{226} \mathrm{Ra}$ & 14.63 & 0.35 & 0.29 & 0.17 \\
\hline & ${ }^{228} \mathrm{Ra}$ & 12.61 & 0.53 & 0.25 & 0.15 \\
\hline & ${ }^{40} \mathrm{~K}$ & 22.95 & 0.53 & 0.45 & 0.27 \\
\hline & ${ }^{137} \mathrm{Cs}$ & 0.80 & 0.16 & 0.02 & 0.01 \\
\hline & Total Terrestrial & 51.00 & 0.84 & & \\
\hline & Total with Cosmic & 85.16 & & & \\
\hline \multicolumn{6}{|l|}{726.2} \\
\hline & ${ }^{226} \mathrm{Ra}$ & 16.47 & 0.35 & 0.20 & 0.14 \\
\hline & ${ }^{228} \mathrm{Ra}$ & 16.99 & 0.61 & 0.21 & 0.15 \\
\hline & ${ }^{40} \mathrm{~K}$ & 23.56 & 0.53 & 0.28 & 0.20 \\
\hline & ${ }^{137} \mathrm{Cs}$ & 22.57 & 3.02 & 0.27 & 0.19 \\
\hline & ${ }^{152} \mathrm{Eu}$ & 3.18 & 1.67 & 0.04 & 0.03 \\
\hline & ${ }^{60} \mathrm{Co}$ & 1.41 & 0.58 & 0.02 & 0.01 \\
\hline & Total Terrestrial & 84.18 & 3.61 & & \\
\hline & Total with Cosmic & $=118.3$ & & & \\
\hline \multicolumn{6}{|l|}{727.1} \\
\hline & ${ }^{226} \mathrm{Ra}$ & 19.53 & 0.44 & 0.30 & 0.20 \\
\hline & ${ }^{228} \mathrm{Ra}$ & 15.59 & 0.61 & 0.24 & 0.16 \\
\hline & ${ }^{40} \mathrm{~K}$ & 27.33 & 0.61 & 0.42 & 0.27 \\
\hline & ${ }^{137} \mathrm{Cs}$ & 3.31 & 0.14 & 0.05 & 0.03 \\
\hline & Total Terrestrial & 65.77 & 0.98 & & \\
\hline & Total with Cosmic & 99.93 & & & \\
\hline
\end{tabular}

${ }^{\dagger}$ Cosmic dose rate estimated 
TABLE 8

FRACTION OF TOTAL DOSE RATE FROM ANTHROPOGENIC SOURCE FOR SEVERAL TOWNS

\begin{tabular}{lcc}
\hline Site ID & Location & $\begin{array}{c}\text { Fraction of Total Terrestrial Dose Rate from } \\
\text { Anthropogenic Sources }\end{array}$ \\
\hline 719.2 & Berioska & $0.02\left({ }^{137} \mathrm{Cs}\right)$ \\
720.1 & Sarzhal & $0.09\left({ }^{137} \mathrm{Cs}\right)$ \\
720.2 & Sarzhal & $0.08\left({ }^{137} \mathrm{Cs}\right)$ \\
721.1 & Kainar & $0.04\left({ }^{137} \mathrm{Cs}\right)$ \\
721.2 & Kainar & $0.06\left({ }^{137} \mathrm{Cs}\right)$ \\
721.3 & Kainar & $0.04\left({ }^{137} \mathrm{Cs}\right)$ \\
722.2 & Akzhar & $0.09\left({ }^{137} \mathrm{Cs}\right)$ \\
726.2 & Farm & $0.33\left(0.27{ }^{137} \mathrm{Cs}, 0.04{ }^{152} \mathrm{Eu}, 0.02{ }^{60} \mathrm{Co}\right)$ \\
727.1 & Dolon (soil) & $0.05(0.09)\left({ }^{137} \mathrm{Cs}\right)$ \\
\hline
\end{tabular}




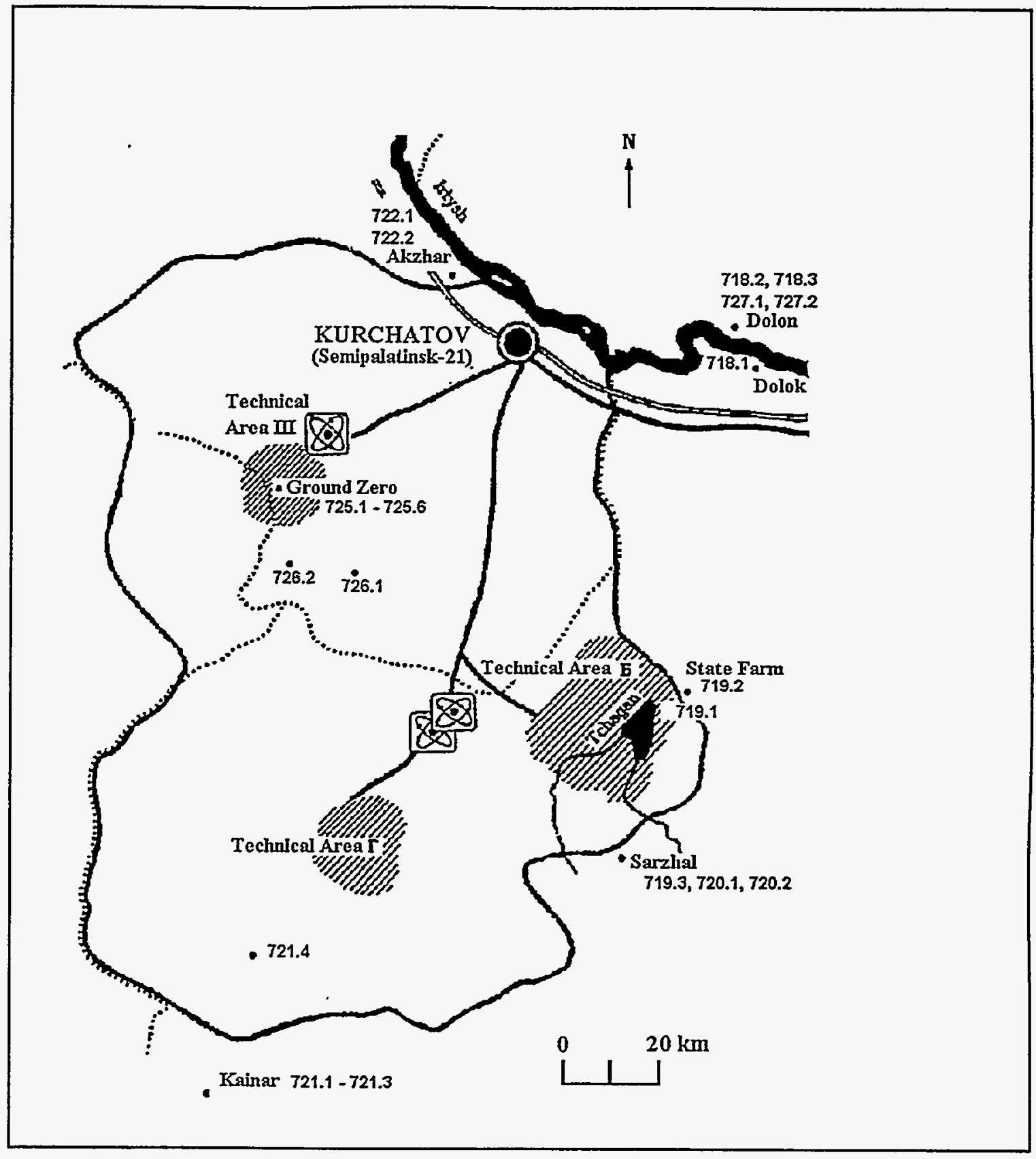

Figure 1 Map of sampling locations. Numbers refer to site identifications described in Table 1. 


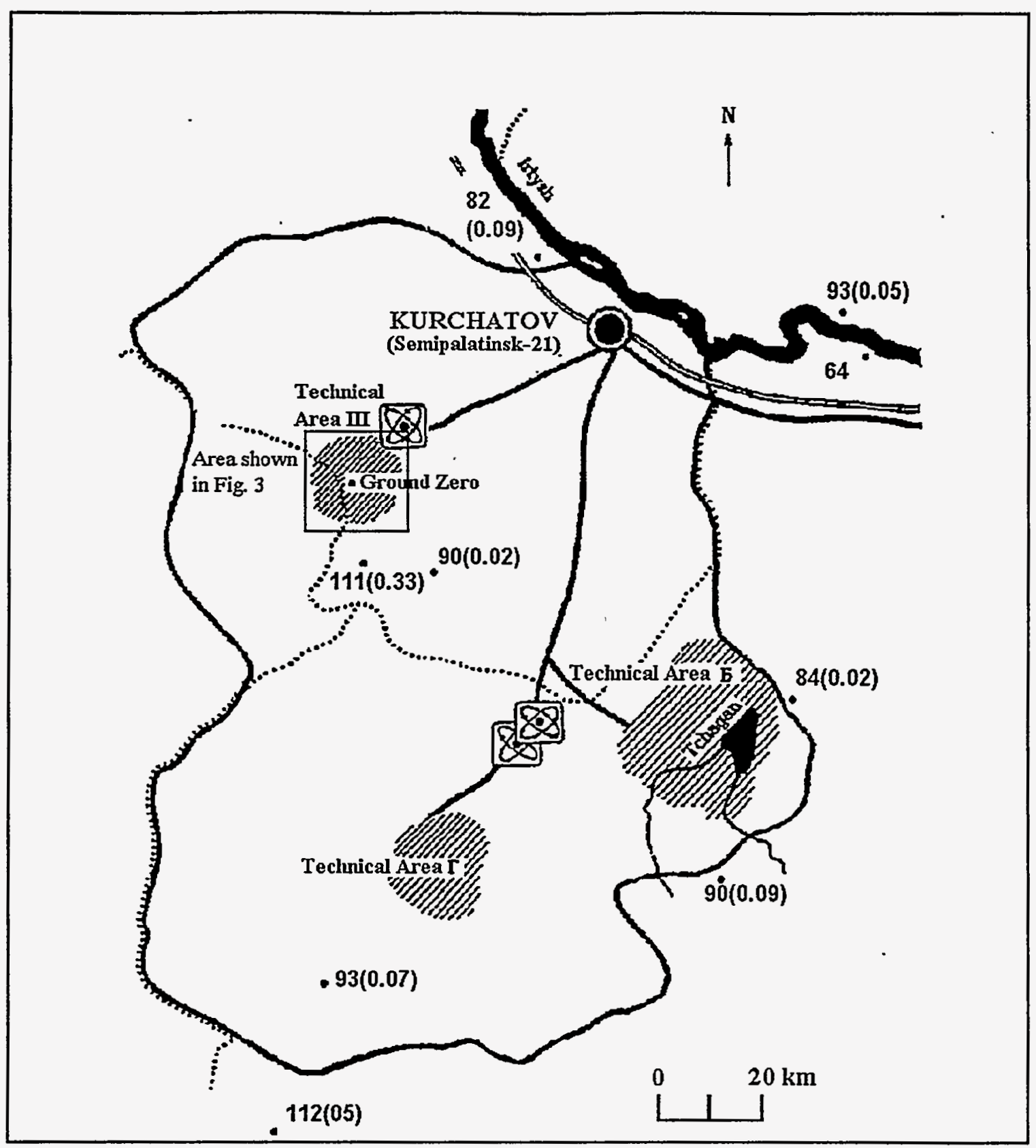

Figure 2 Map (excluding area surrounding ground zero) of absorbed dose rates in air in $\mathrm{nGy} \mathrm{h}^{-1}$ of sites visited. Values are averages from pressurized ionization chamber measurements, in situ gamma spectrometry measurements, and analyses of soil samples. In parentheses is the ratio of the anthropogenic contribution to the given absorbed dose rate. 


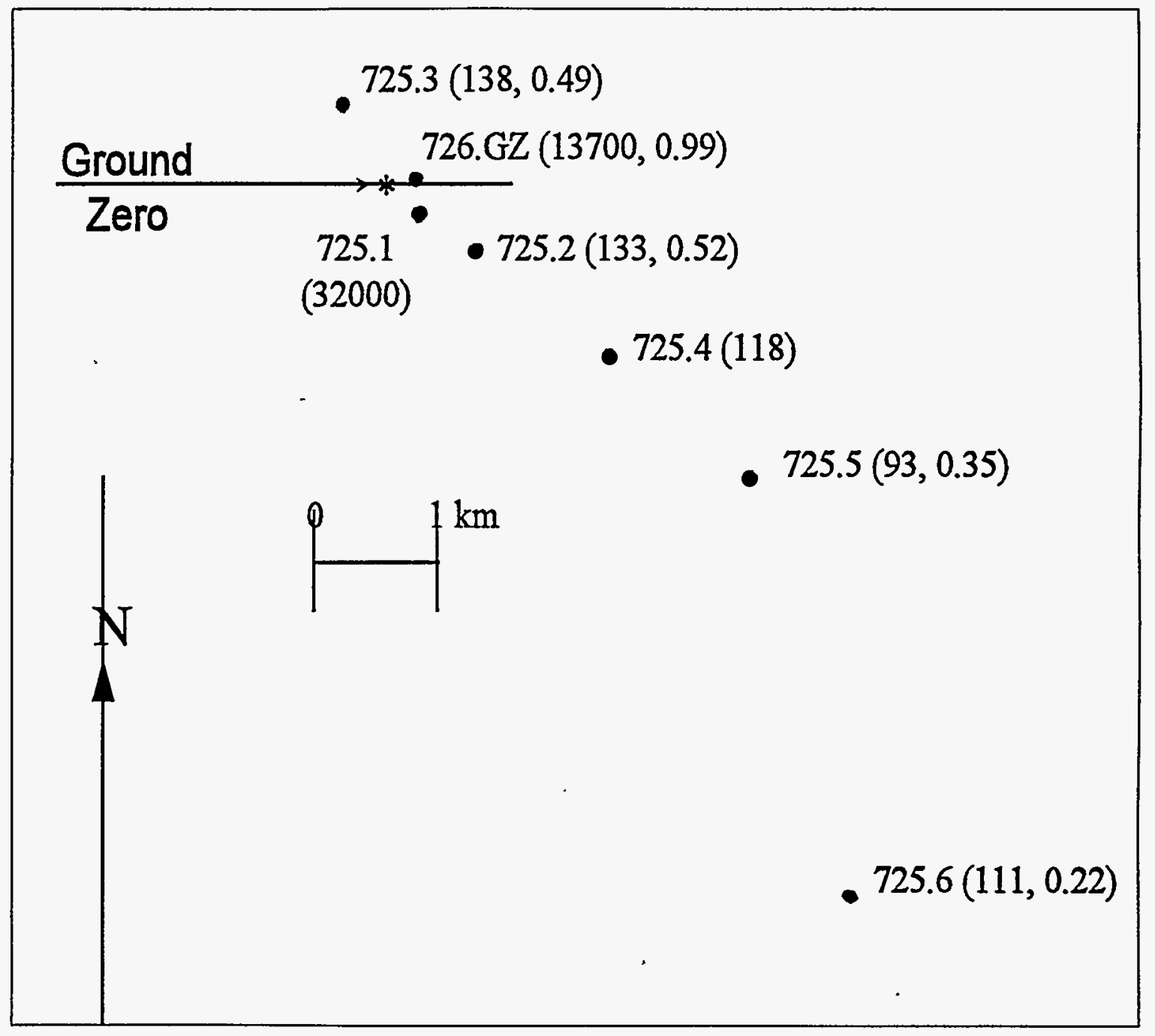

Figure 3 Map of area surrounding ground zero showing location ID's (refer to Table 1 for description). The first value in parentheses is an average value of absorbed dose rates in air in $n G y h^{-1}$ from pressurized ionization chamber measurements, in situ gamma spectrometry measurements, and analyses of soil samples, where available (see Table 1). The second value in parentheses, where available, is the ratio of the anthropogenic contribution to the given absorbed dose rate. 
IAEA Mission to Kazakhstan Team Member List:

Aḍam R. Hutter, USDOE/EML

Anatoly Matushchenko, Ministry of Atomic Industry, Russia

Anthony Wrixon, Associate Director, National Radiological Protection Board, UK

Christian Chanel, French Atomic Energy Agency

Daniel LaRoue, University of Paris

Igor Kuleshov, translator, IAEA

Jerry LaRosa, Siebersdorf Laboratories, IAEA

Peter Shaw, National Radiological Protection Board, UK

Peter Stegnar (team leader), Division of Nuclear Safety, IAEA

Peter Shebell, USDOE/EML

V. Smakulov, Military and Ministry of Atomic Industry, Russia 